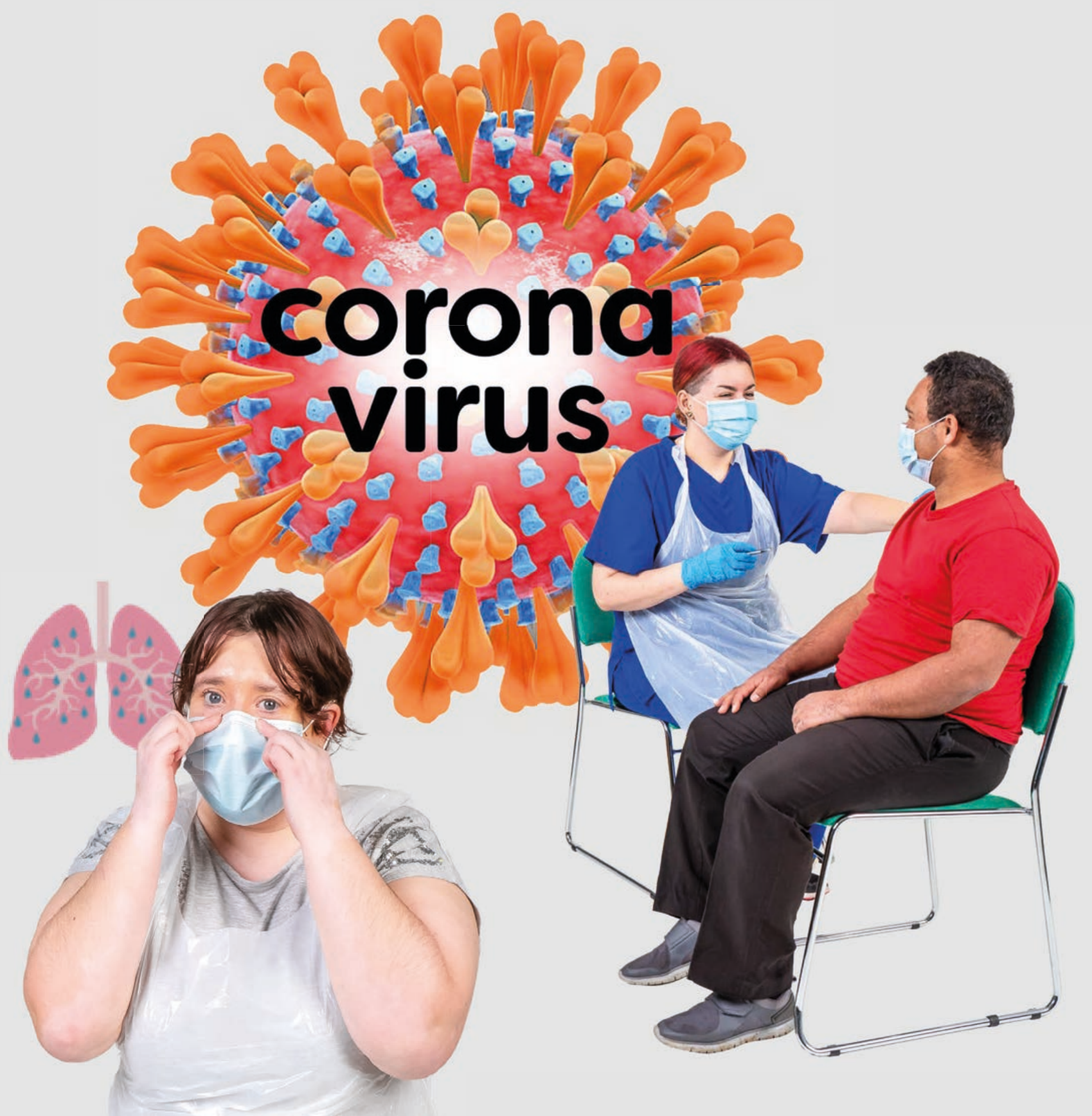

This information sheet is about COVID-19.

It is especially for people with lung problems, but most of the information helps everybody. 


\section{What is COVID-19?}
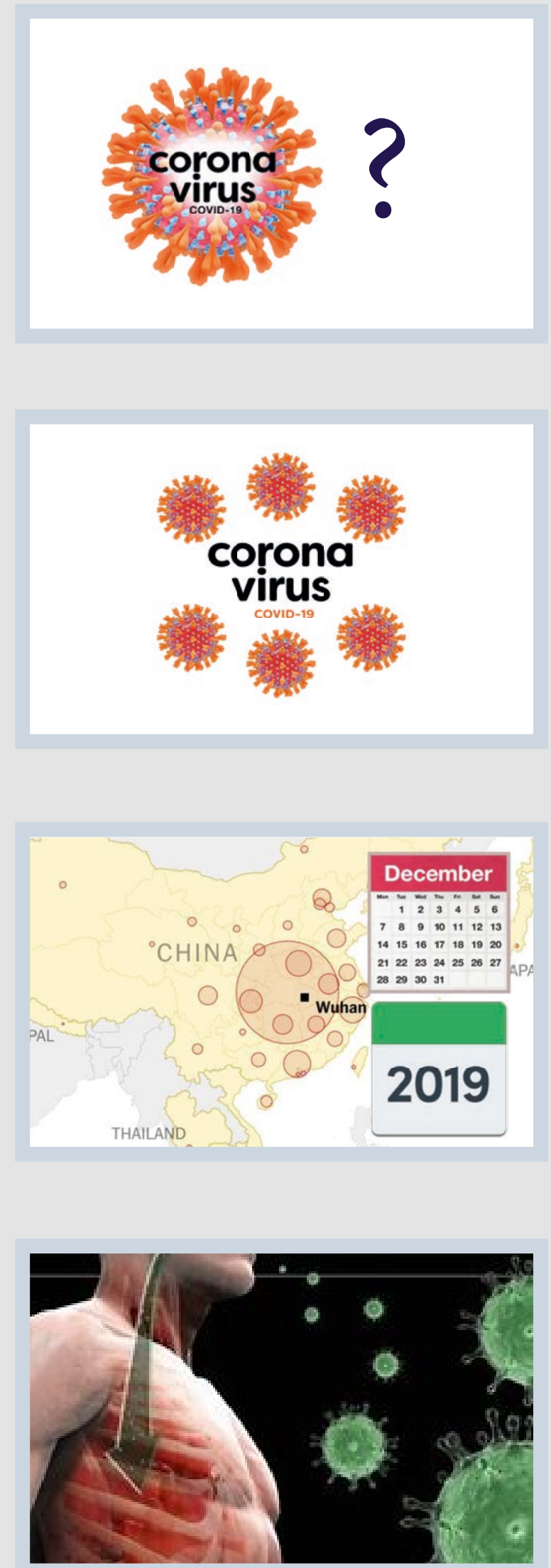

COVID-19 is also called

Coronavirus disease 2019.

It is caused by something called SARS-Cov-2, Severe Acute Respiratory Syndrome Coronavirus 2.

It was first reported in humans in December 2019 in Wuhan, China.

There are lots of types of Coronaviruses, including a common cold, pneumonia and ARDS, Acute Respiratory Distress Syndrome. 

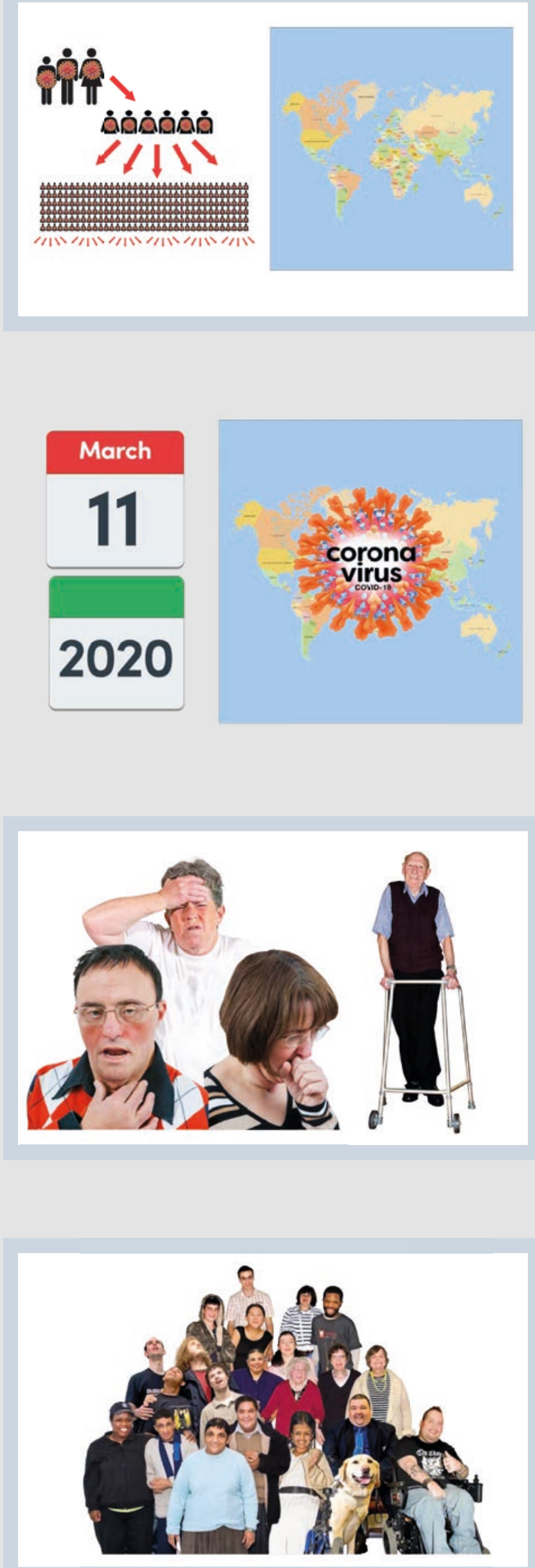

COVID-19 spreads between people very easily and lots of people around the world are getting it.

The World Health Organization, WHO, said it was a global pandemic on 11th March 2020. This means it is a problem across the world.

Some people become more ill than others. People who have medical problems and older people have suffered more.

It can affect anyone, so everyone needs to be very careful. 


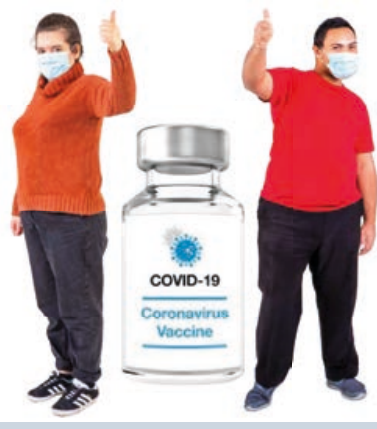

\section{How does having a lung condition affect me becoming ill with COVID-19?}

We are still learning about how to treat people with COVID-19. There are now vaccines to help stop it.
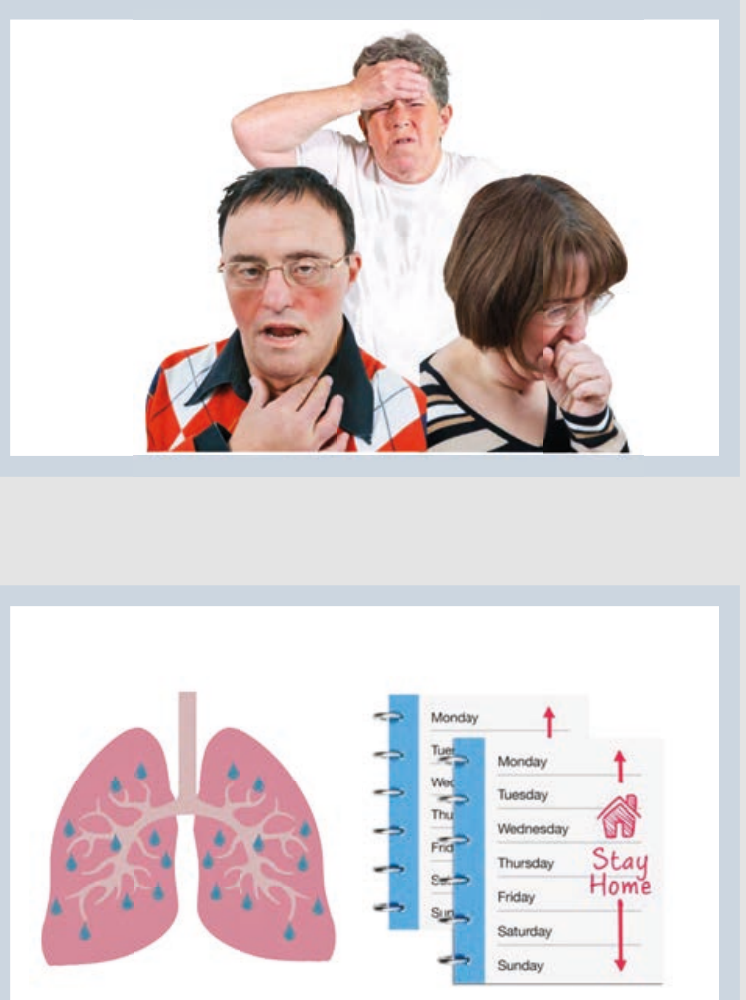

You are not more likely to get

COVID-19 because you have a lung condition now, or had one in the past.

It may mean that you it affects you more if you get COVID-19, or how long it takes to get better. 

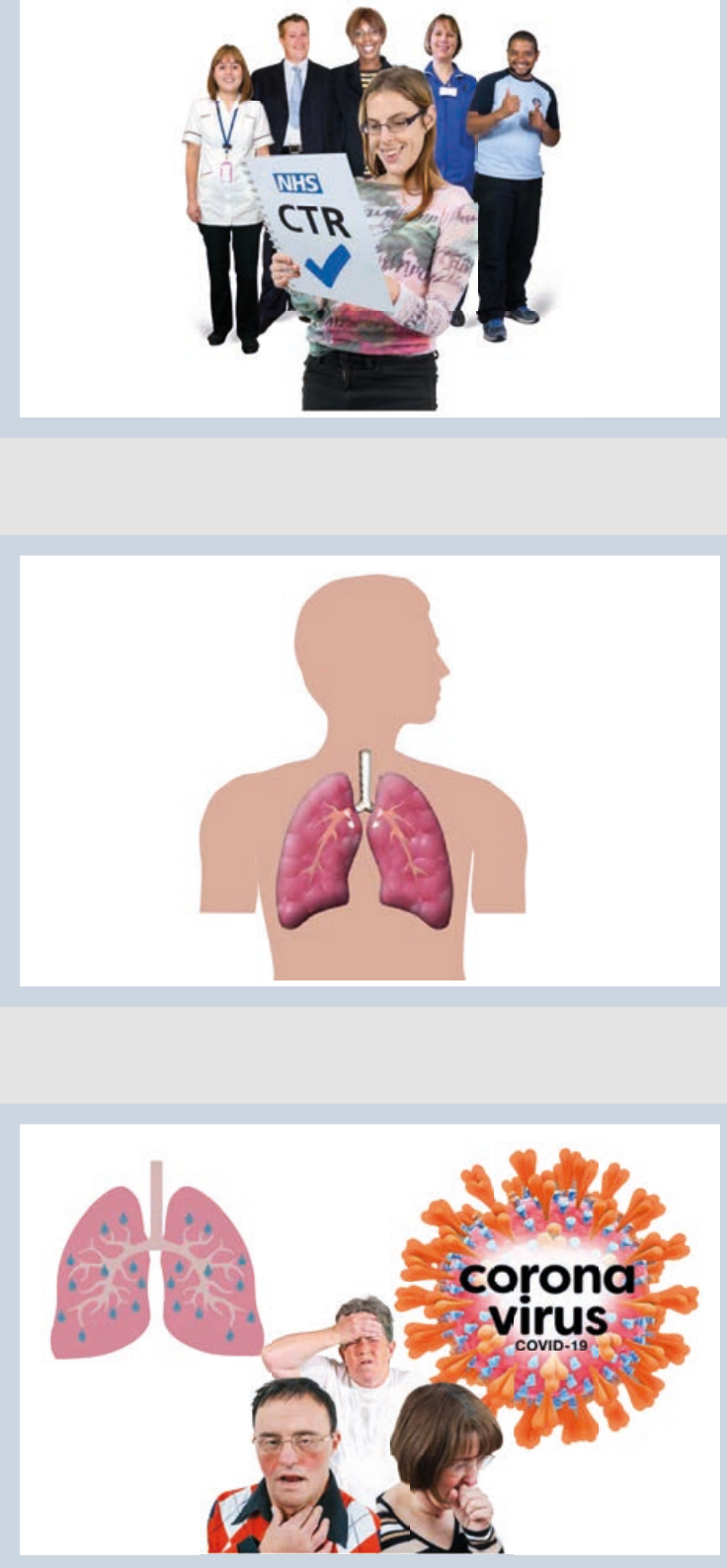

Whatever lung condition you have, carry on with the treatment your doctor has told you to have.

Only stop if your doctor tells you to. Including medication and physiotherapy.

If you have had a lung condition and are now better with no breathing problems, you are not in more danger of being ill from COVID-19.

This includes pneumonia, collapsed lung or punctured lung.

Some lung conditions can make it harder for people if they catch COVID-19. Some of these are:

- Asthma

- Bronchiectasis

- COPD

- Cystic fibrosis

- Emphysema

- Idiopathic pulmonary fibrosis (IPF)

- Immune disorders that have affected the lung (for example, lupus and rheumatoid arthritis

- Lung cancer 


\section{What can I do to help stop me catching or spreading COVID-19?}
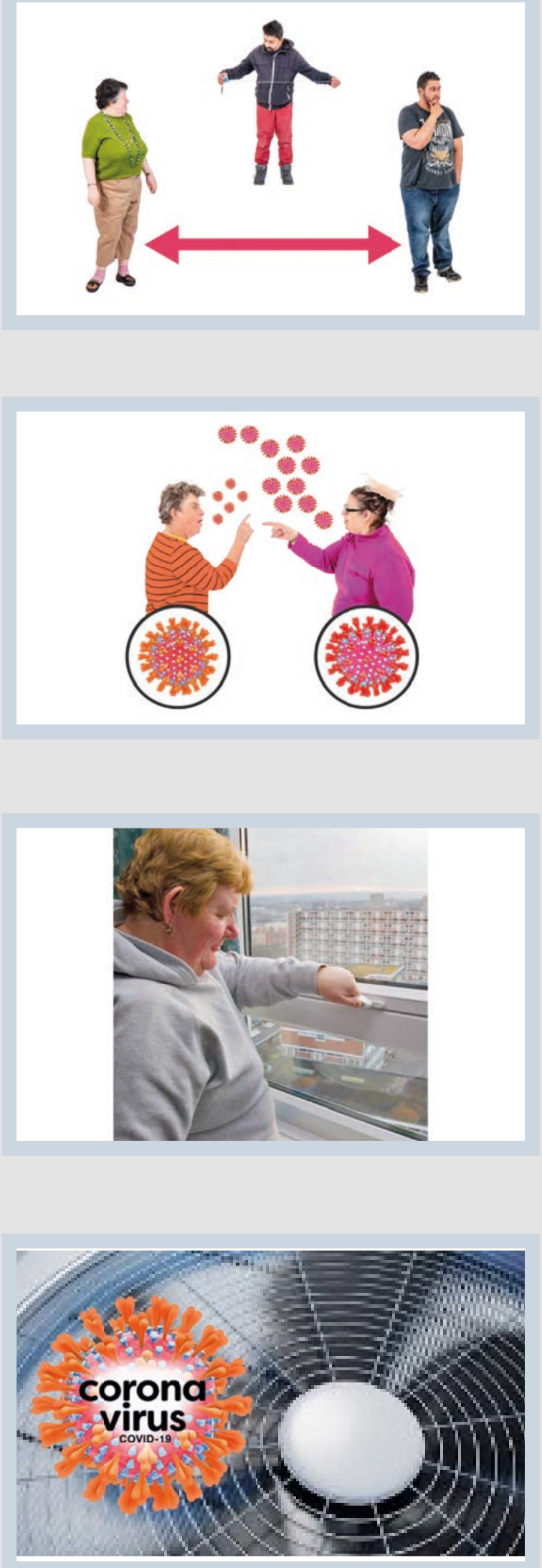

\section{Social distancing}

Rules can be different in each country.

Stay more than 2 metres away from people that you do not live with.

The COVID-19 virus mostly spreads from one person to another in tiny drops of liquid in our breath. So it is better to be further away from someone so that you are not sharing the air you breathe.

When you are inside with someone you do not live with, open windows to have fresh air coming in.

Air conditioning and fans blowing can make the virus spread more. 


\section{Hand washing}

Washing hands is the most important way to stop the virus.

Soap helps to kill the virus and stop it from spreading.

Wash your hands for more than 20 seconds with soap to kill the virus.

If you cannot wash your hands, use alcohol gel, also called hand sanitizer with $60 \%$ or more alcohol. Then wash your hands as soon as you can.

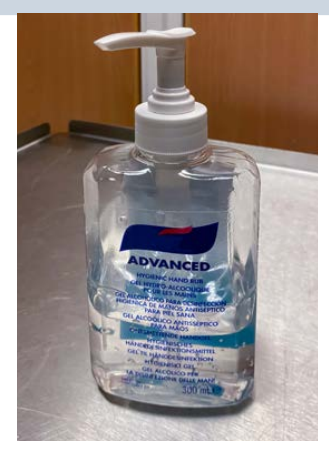




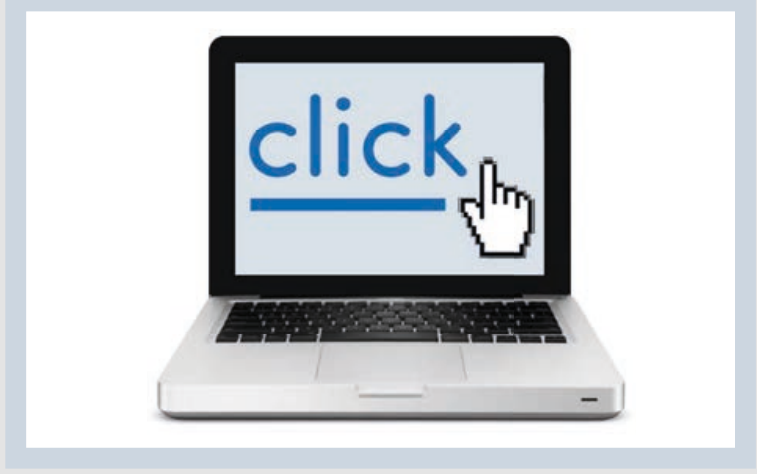

Our website shows how to clean your hands well: www.europeanlung.org/en covid-19/what-iscovid-19prevention

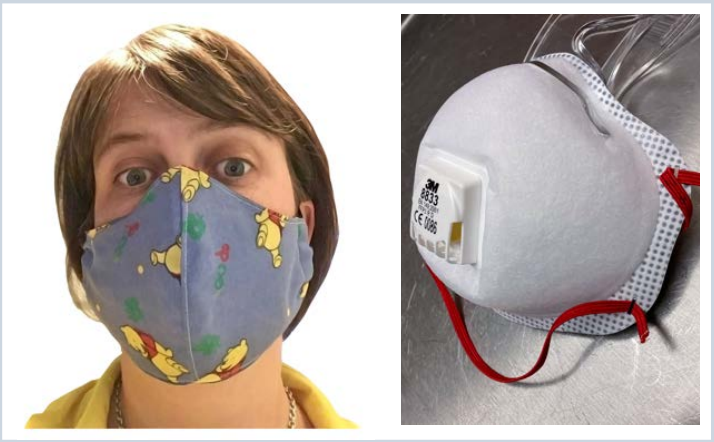

\section{Face coverings}

Face coverings, also called masks, can help stop the spread of coronavirus.

They help to stop our droplets from spreading from one person to another in our breath.

Coughing and sneezing spreads droplets onto surfaces and in the air.

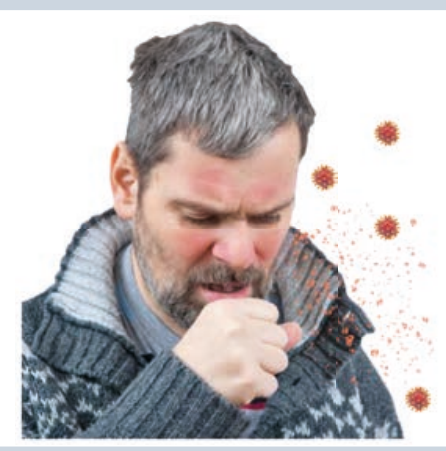



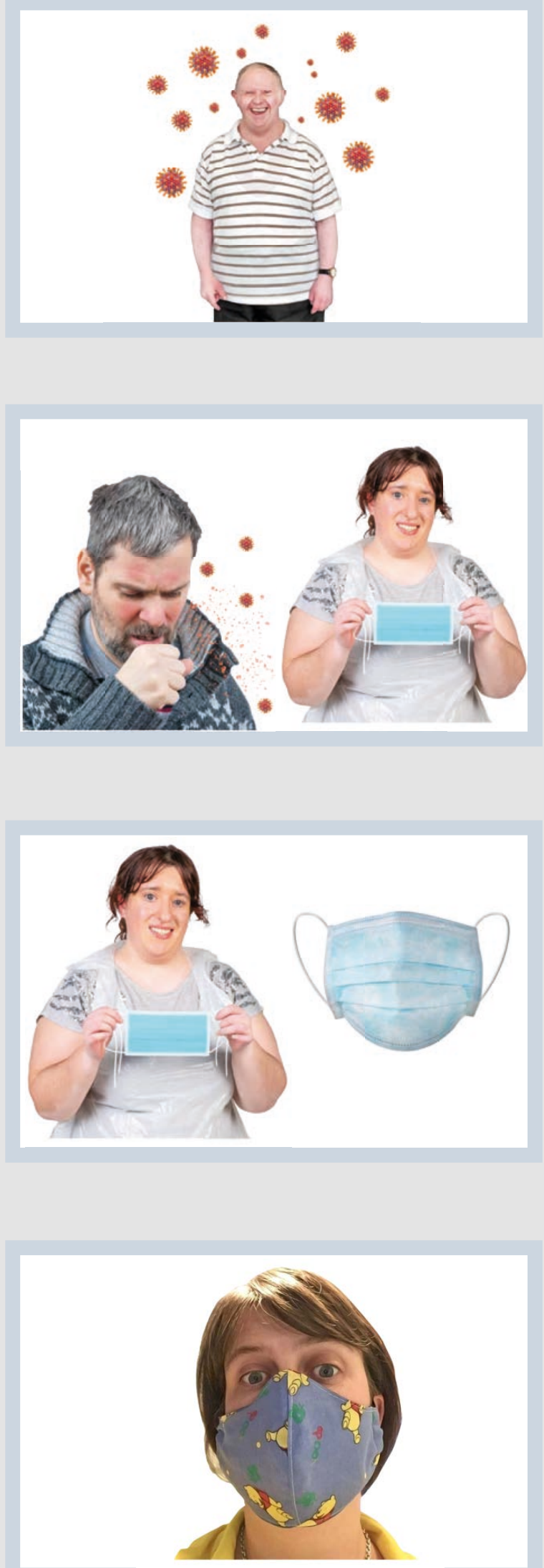

People may have COVID-19 but they do not know that they have it. They can spread it without realising.

If you cough or sneeze when you are wearing your face covering, take it off and put on a clean one. This is because it may be full of droplets. It will not work as well when wet.

Dry face coverings work better.

Make sure your nose and mouth are covered with the face covering. 

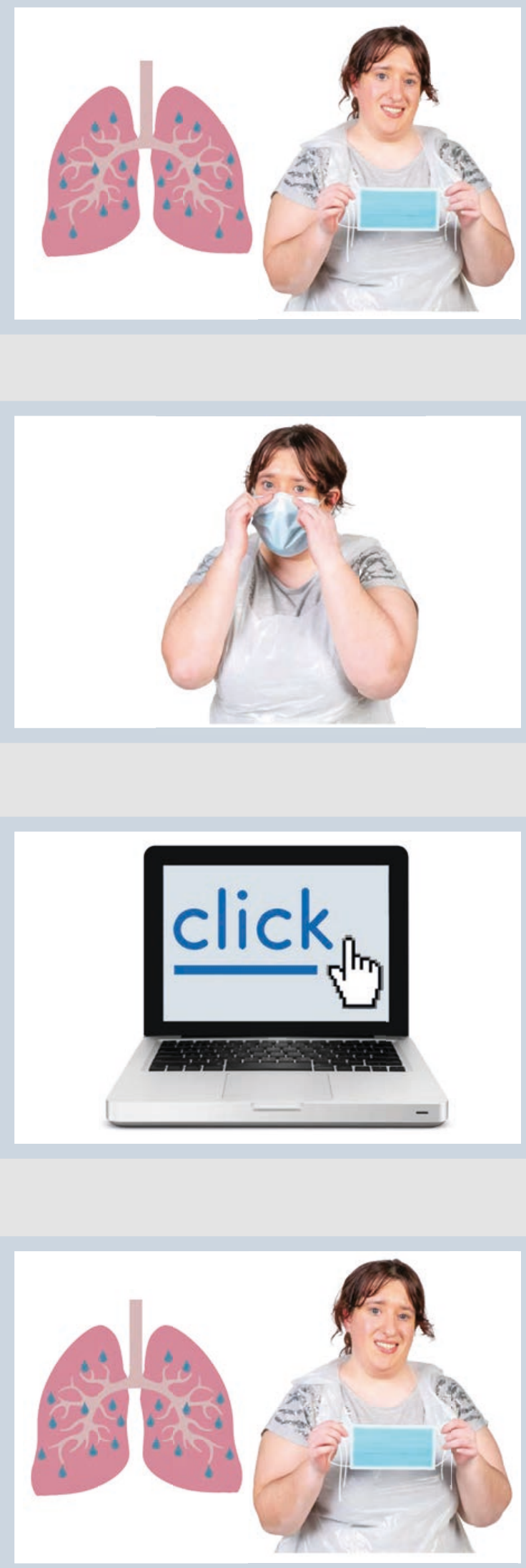

If you have a lung condition, you should still be able to wear a face covering.

It may feel harder to breathe when you are wearing it, but there are some things you can do to get used to having it on.

We have some information on our website to help understand face coverings:

www.europeanlung.org/en/ covid-19/covid-19-informationand-resources/wearing-a-mask-orface-covering-if-you-have-a-lungcondition

It is important for people with lung conditions to wear a face covering. 

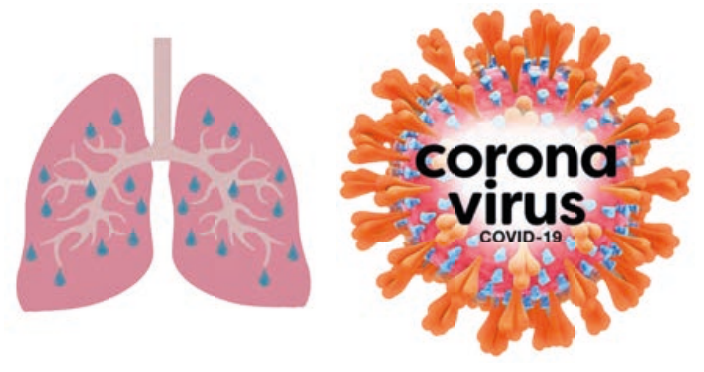

Some of the symptoms of COVID-19 may feel like some of the symptoms of the lung condition, so you may not know you have it.

\section{What are the symptoms of COVID-19? How do I know if I have it?}

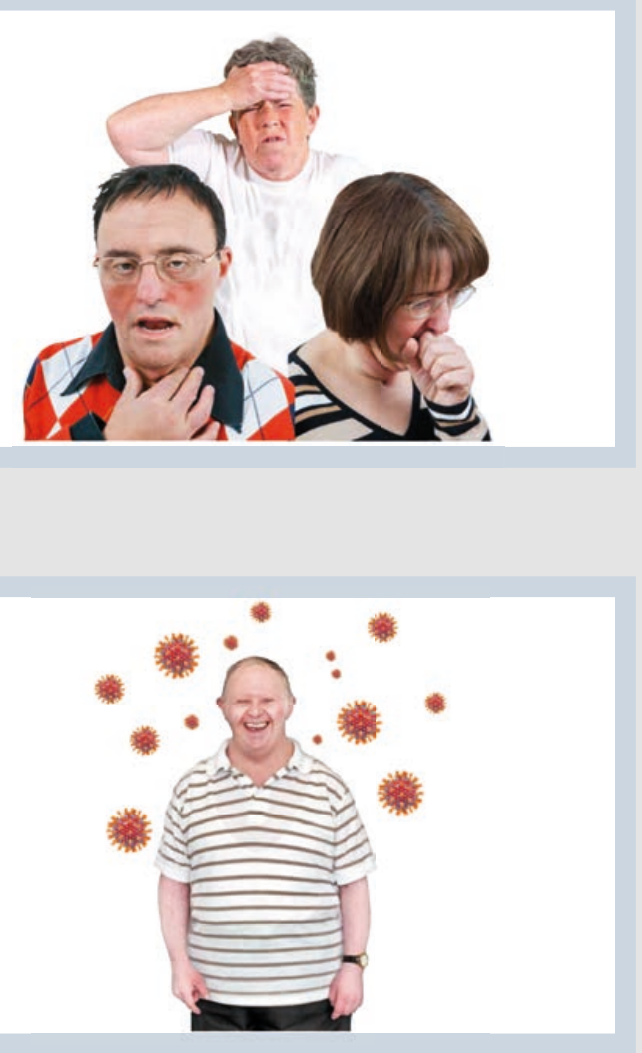

The symptoms, the way people are affected, is different for each person. There are some symptoms that are more usual than others.

Up to half of people who get COVID-19 have very mild symptoms, or do not show any symptoms at all. 

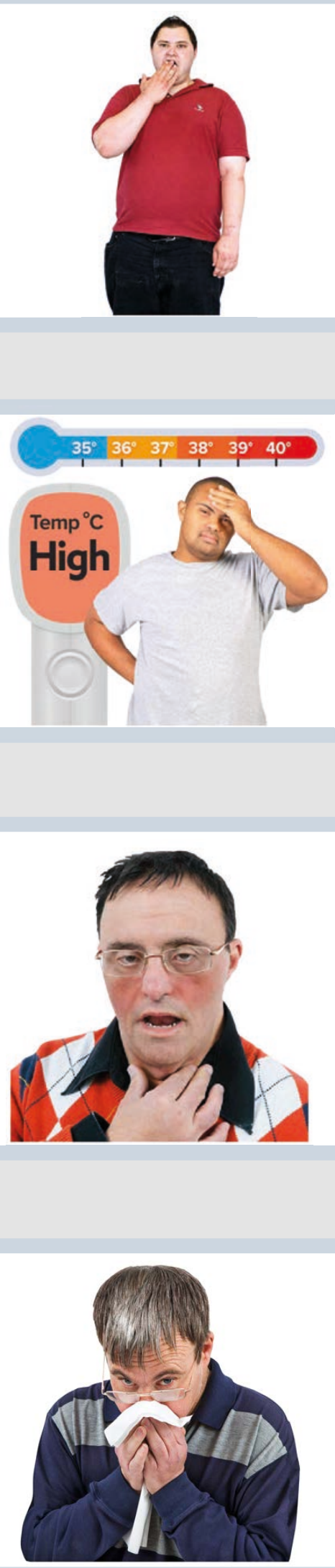

\section{Mild Symptoms}

Mild symptoms may include:

- Feeling very tired

- A fever (temperature over 38 degrees Celsius)

- A sore or scratchy throat

- Runny nose 

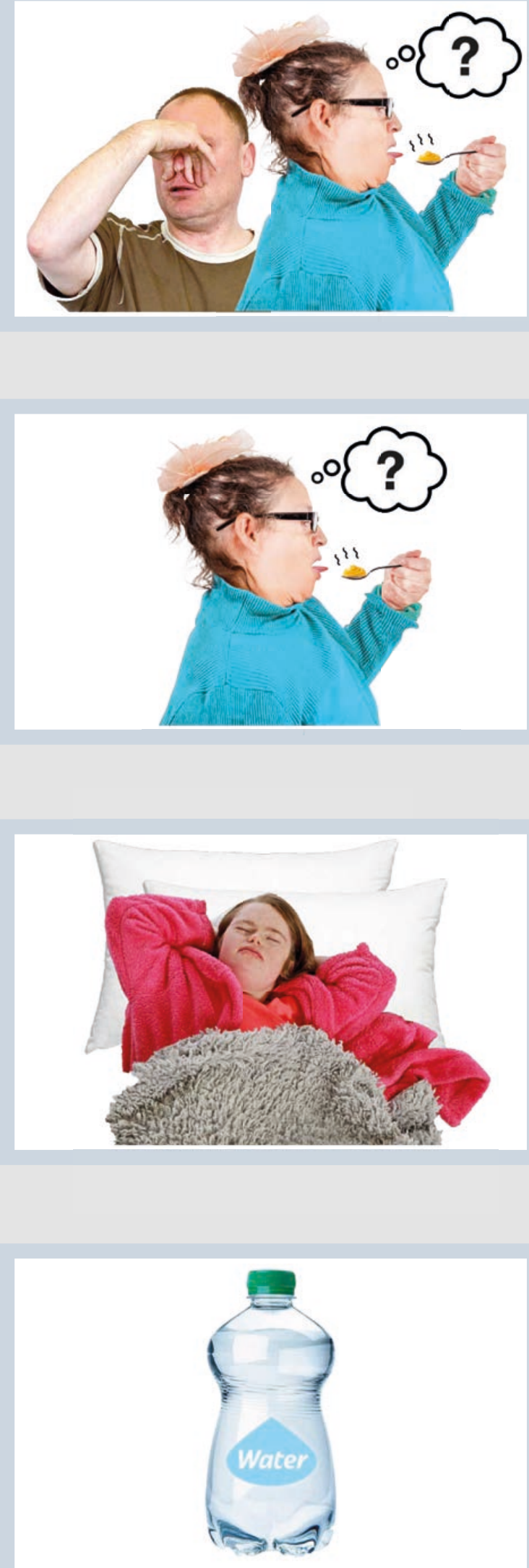

- Loss of sense of smell

- Loss of sense of taste

\section{Treatment to get better}

- Get lots of rest

- Drink plenty of fluids 

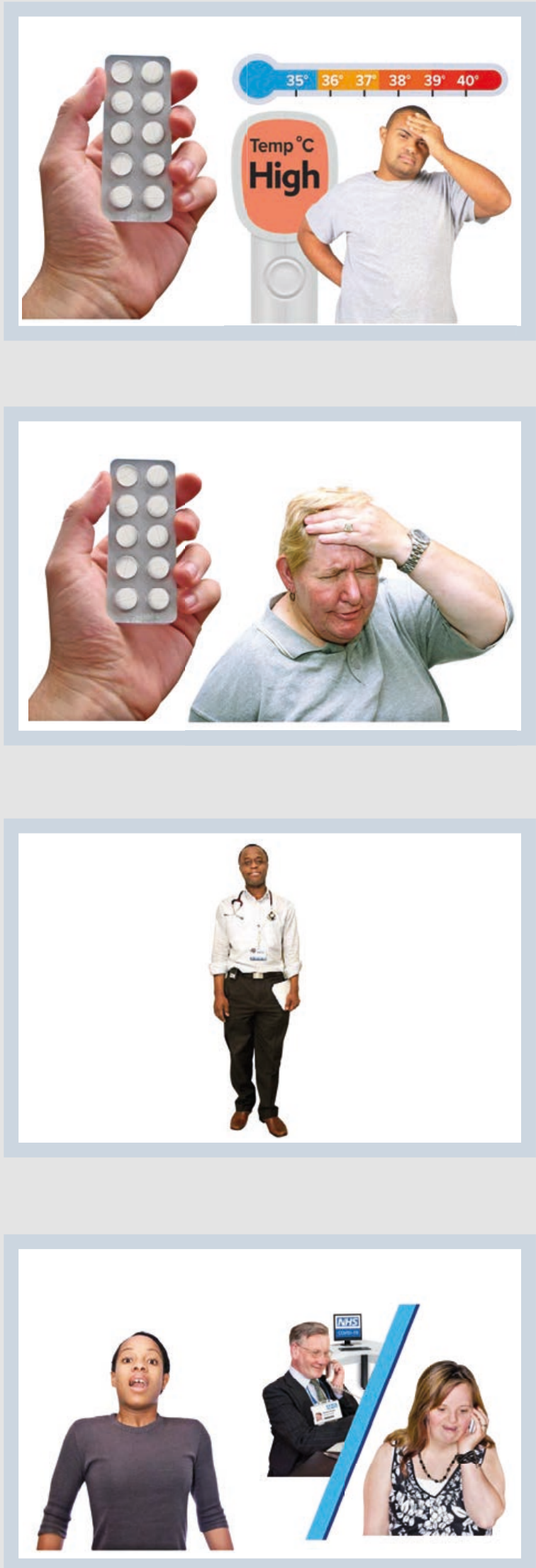

- Paracetamol can help control the fever

- Paracetamol can help control pain.

\section{When to contact a doctor}

If your symptoms are mild, you will probably not need to see a doctor.

If you suddenly feel a lot worse or you are finding it hard to breathe, telephone your doctor. 

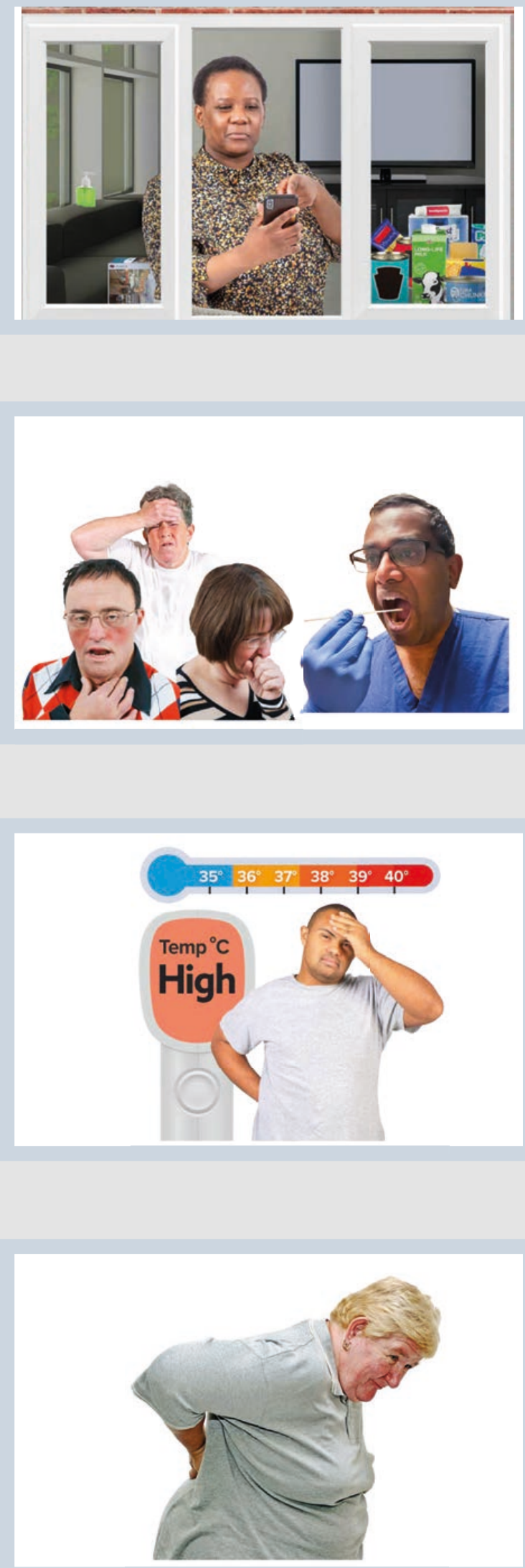

If you have COVID-19 symptoms you should self-isolate, stay at home and keep away from other people.

If you have COVID-19 symptoms you should be tested for the virus.

\section{Moderate symptoms}

Moderate symptoms may include:

- A fever (temperature over 38 degrees Celcius)

- Aching muscles 
- A cough that will not go away

- Finding it hard to breathe

- Headaches

- Feeling very tired

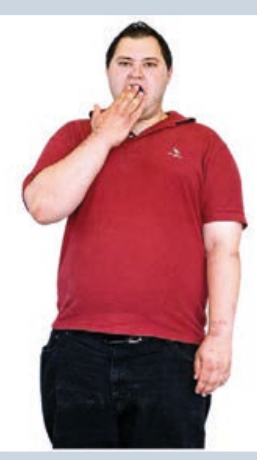


- Not feeling hungry
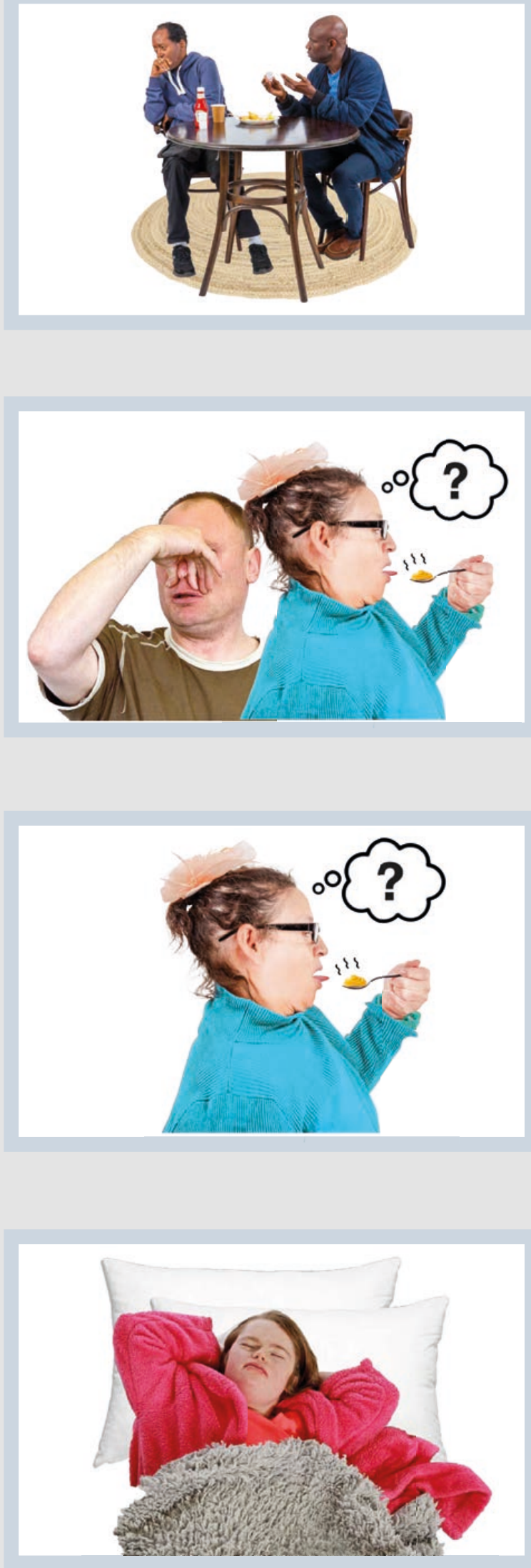

- Loss of sense of smell

- Loss of sense of taste

\section{Treatment to get better}

- Get lots of rest 
- Drink plenty of fluids
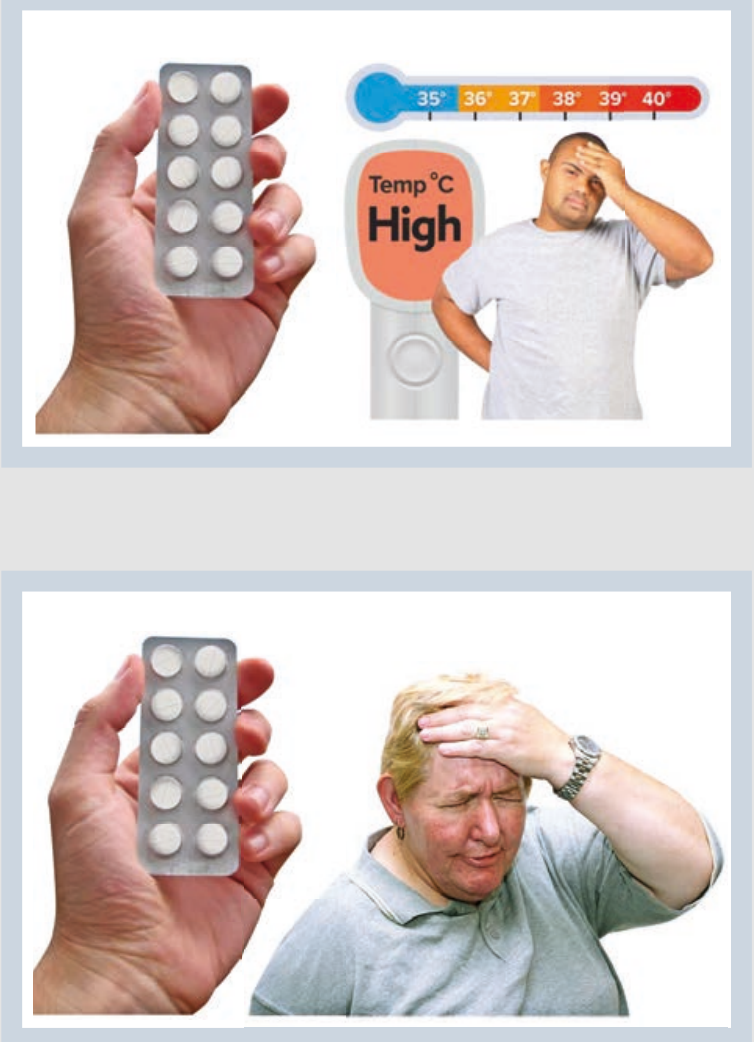

- Paracetamol can help control the fever

- Paracetamol can help control pain.

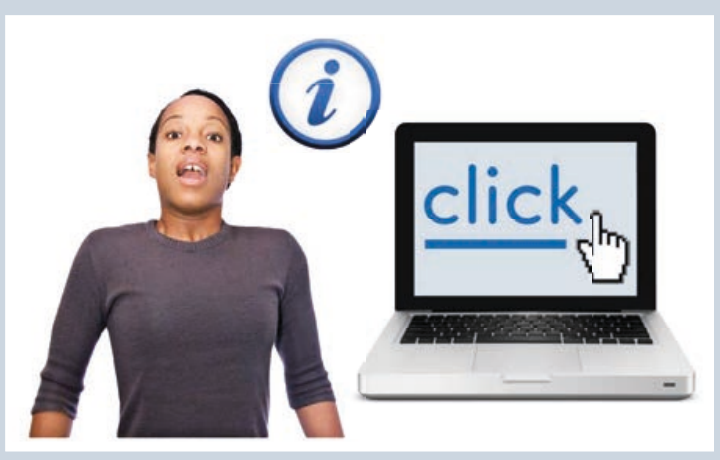

- If you are finding it hard to breathe, we have some advice to help that on our website:

www.europeanlung.org/en/ covid-19/covid-19-informationand-resources/managingbreathlessness-at-home-duringthe -covid-19-pandemic 

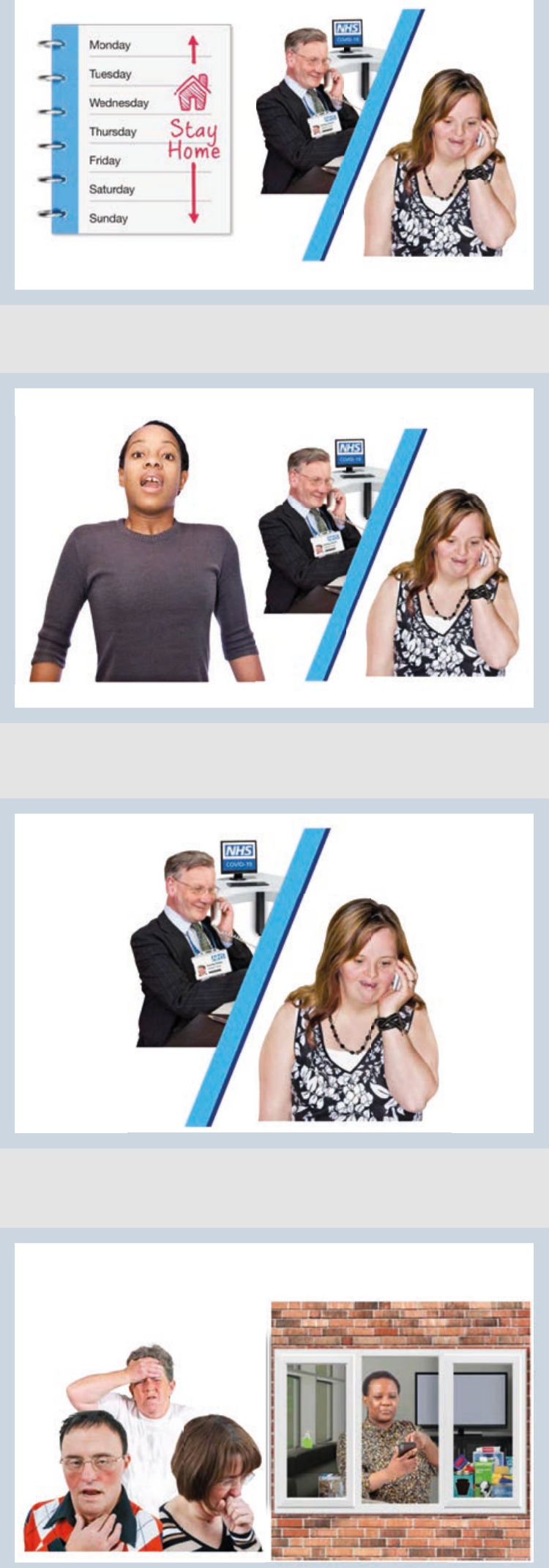

\section{When to contact a doctor}

Contact a doctor if you are not feeling any better after about a week.

Contact a doctor if your symptoms are getting worse, especially if breathing is becoming harder. For example, finding it hard to breathe when walking upstairs.

You should contact your doctor by telephone and not try to go to the clinic or surgery.

If you have COVID-19 symptoms you should self-isolate, stay at home and keep away from other people. 

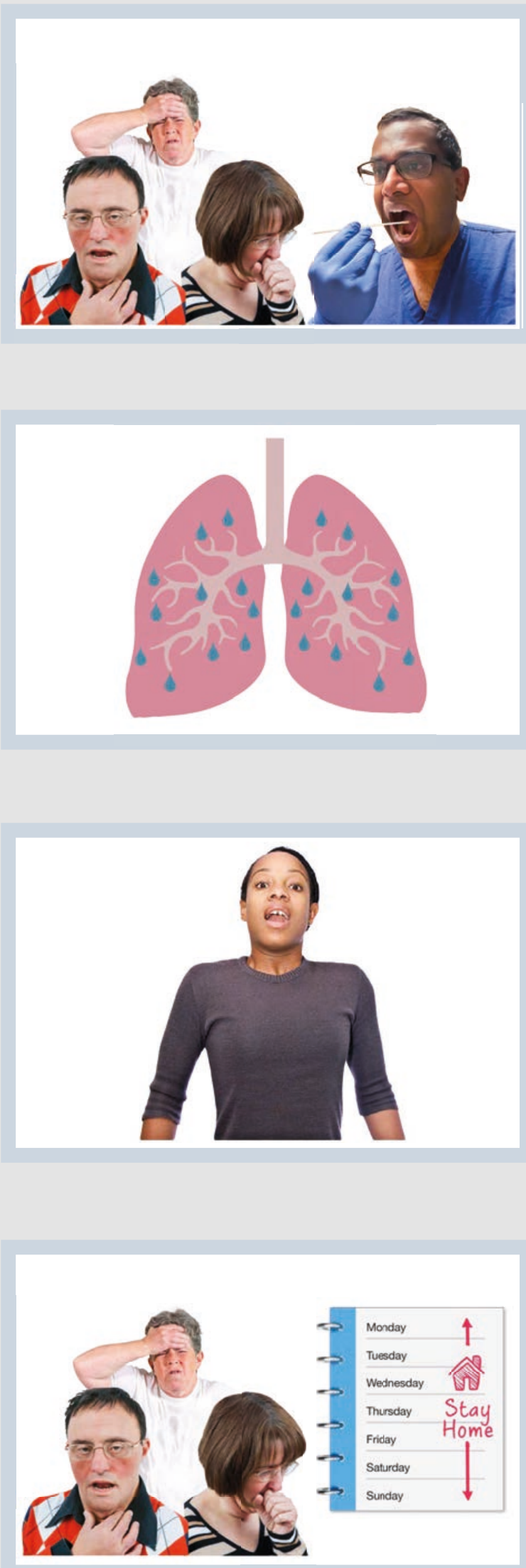

If you have COVID-19 symptoms you should be tested for the virus.

\section{Severe, very bad, symptoms}

One of the worst issues with having COVID-19 is getting pneumonia. This means that the infection is in the lungs.

Finding it hard to breathe may be the worst symptom of COVID-19.

Symptoms of COVID-19 are often at their worst about 1 week after the symptoms have started. 

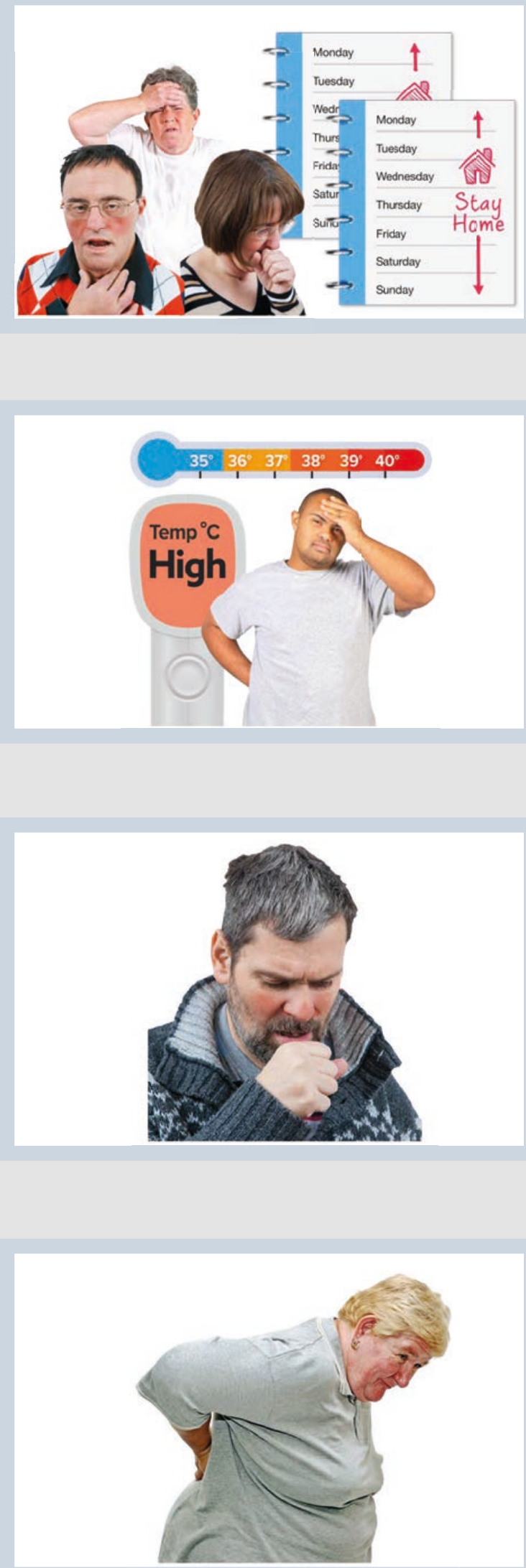

It can take 2-3 weeks for some people to start feeling any better.

People are also likely to have:

- A high fever (temperature over 38 degrees Celcius, or higher)

- A cough that will not go away

- Aching muscles 

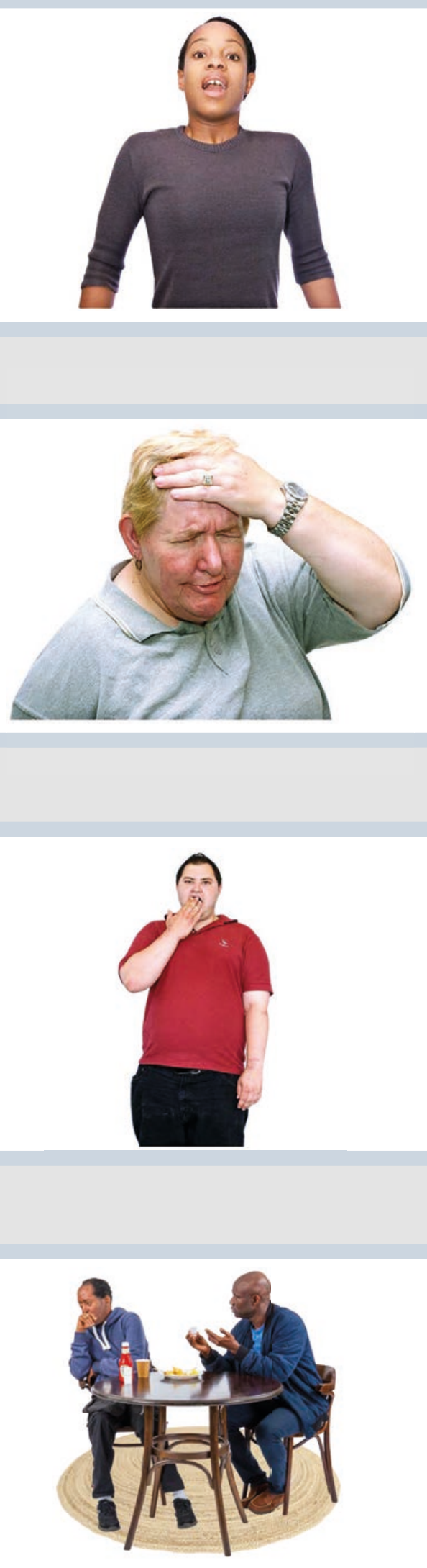

- Finding it hard to breathe

- Headaches

- Feeling tired

- Not feeling hungry 

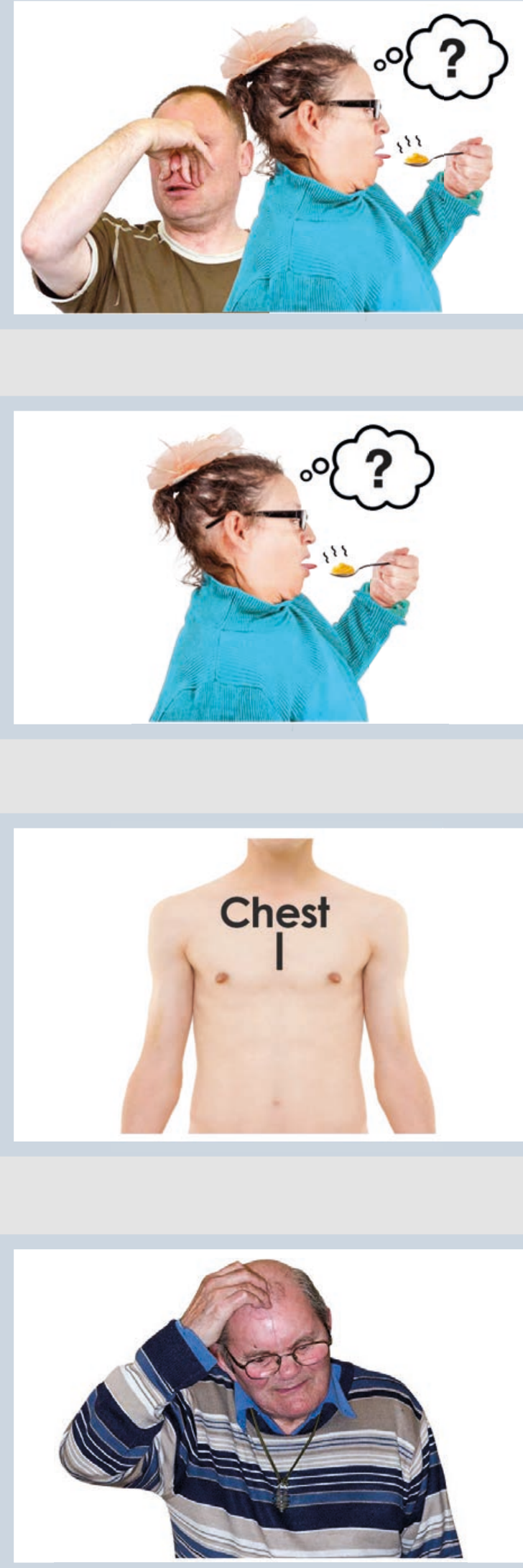

- Loss of sense of smell

- Loss of sense of taste

- Chest pain

- Feeling dizzy 

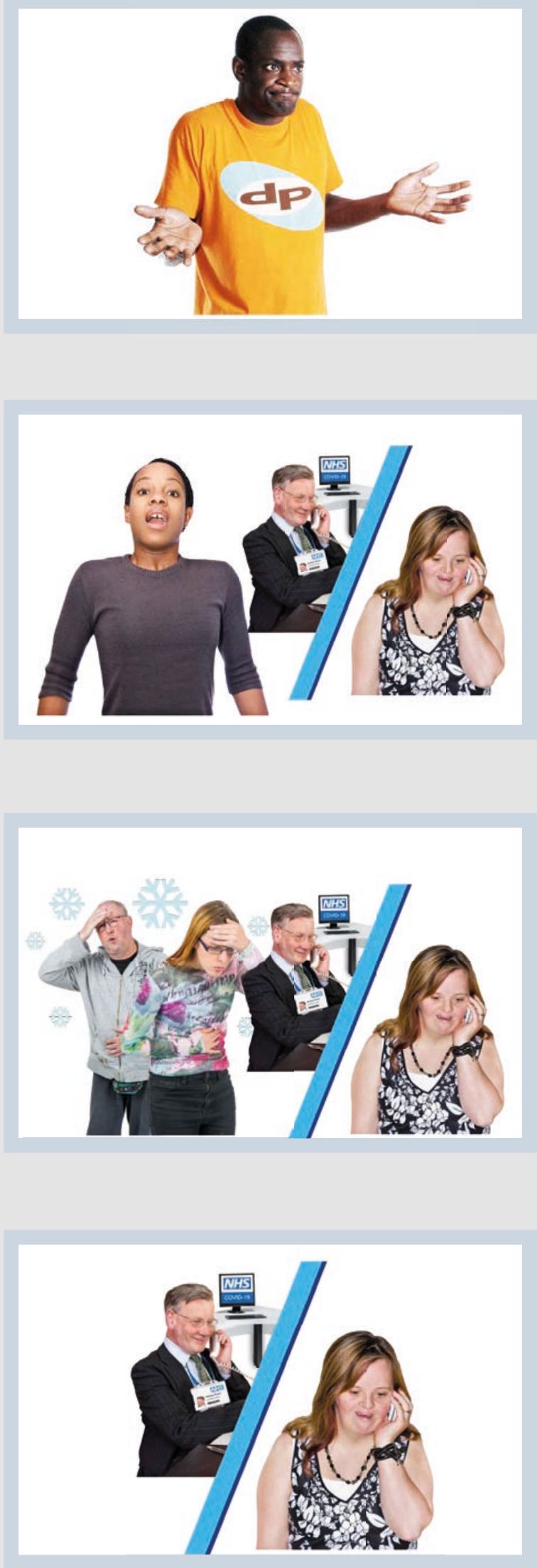

- Feeling confused

\section{When to contact a doctor}

Speak to your doctor if breathing is difficult and you cannot do things like walking up the stairs without stopping.

Speak to your doctor if your symptoms feel worse than having flu.

You should contact your doctor by telephone and not try to go to the clinic or surgery. 

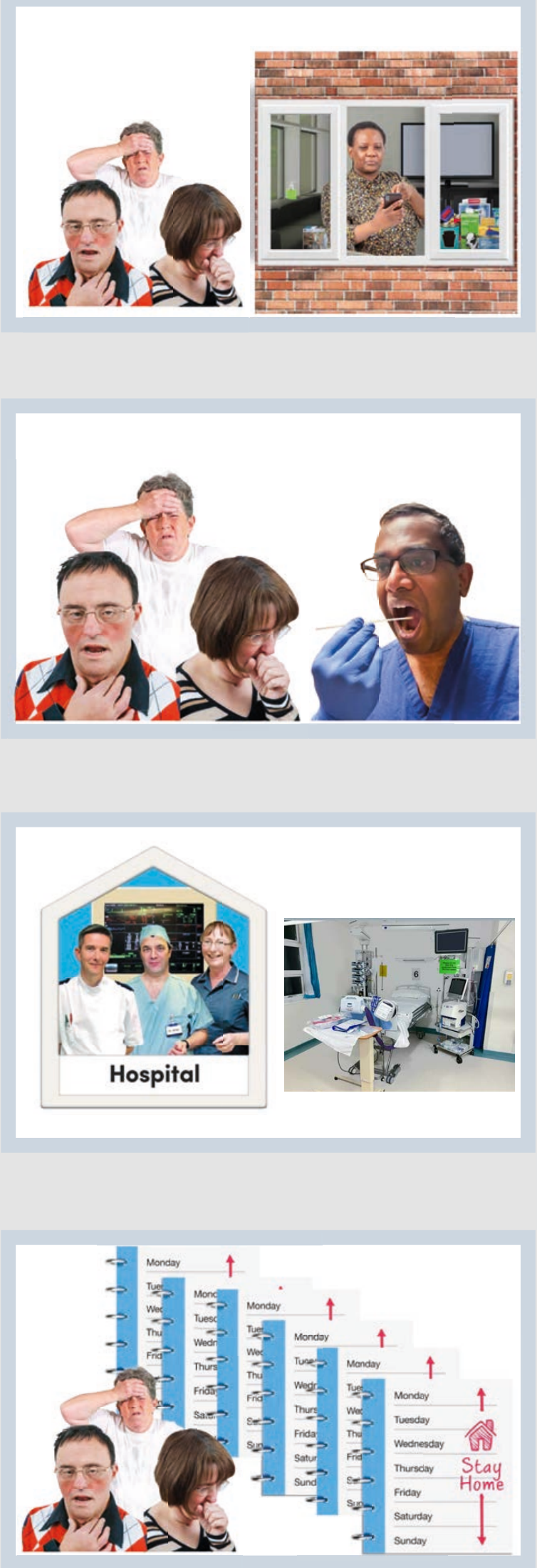

If you have COVID-19 symptoms you should self-isolate, stay at home and keep away from other people.

If you have COVID-19 symptoms you should be tested for the virus.

Severe infections will probably mean some time in hospital for treatment.

People who have a severe infection will probably feel tired and have some symptoms for 6 weeks or more. 

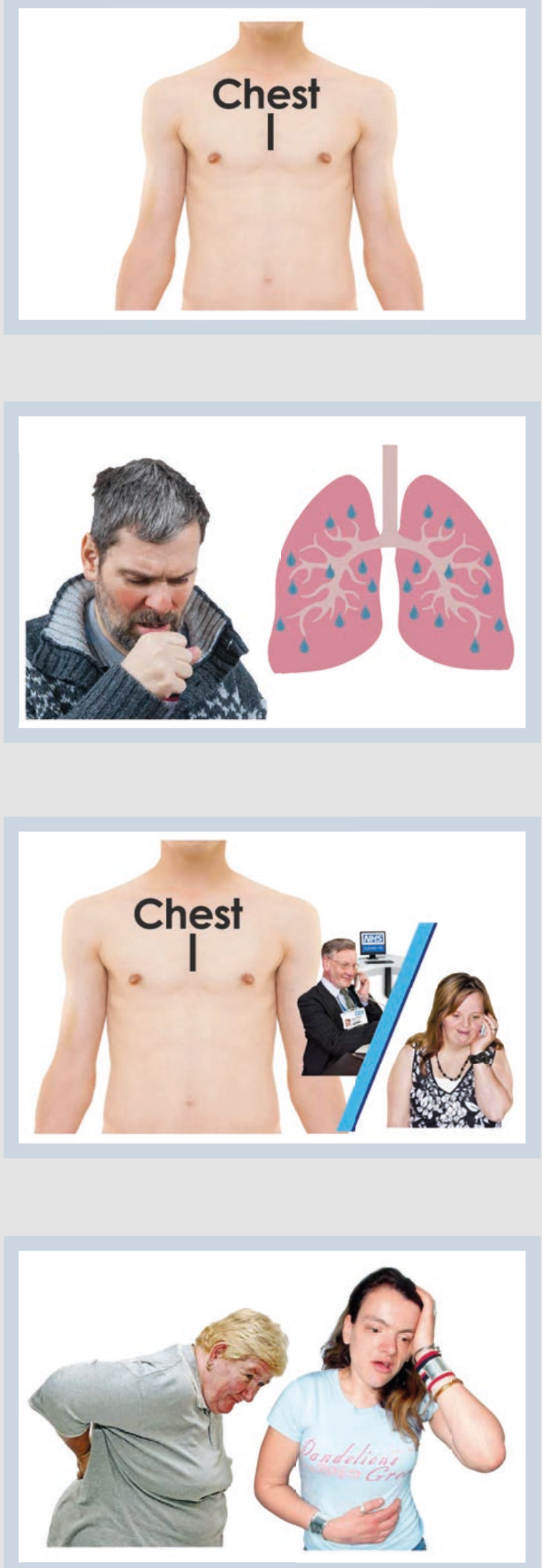

\section{Some more unusual symptoms are:}

Chest pain - 1 in 10 people with COVID-19 may feel a stabbing feeling in their chest.

This is most likely because the lining of the lung is inflamed, sometimes called pleurisy. It is sometimes because of the coughing.

If you have chest pains, it is important that you tell your doctor, as there may be other things that can cause the pain.

People can get pains in their muscles and joints too. 


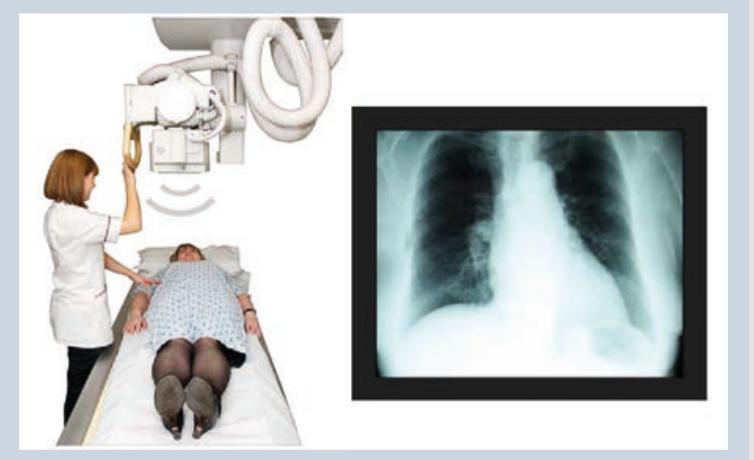

\section{Long COVID}
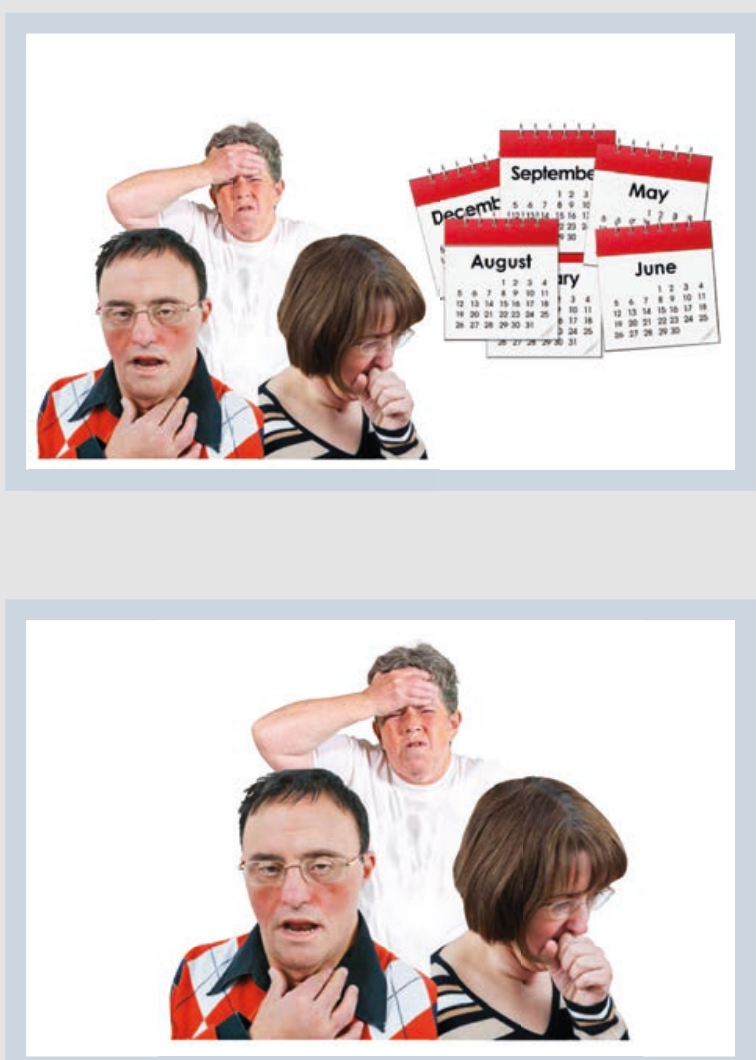

Most symptoms will settle down by themselves, but some people may need an $x$-ray, a scan or other check ups.
People can have symptoms for a short time after having COVID-19, but for others it can last for longer.
Sometimes symptoms can go away, but then come back again. 


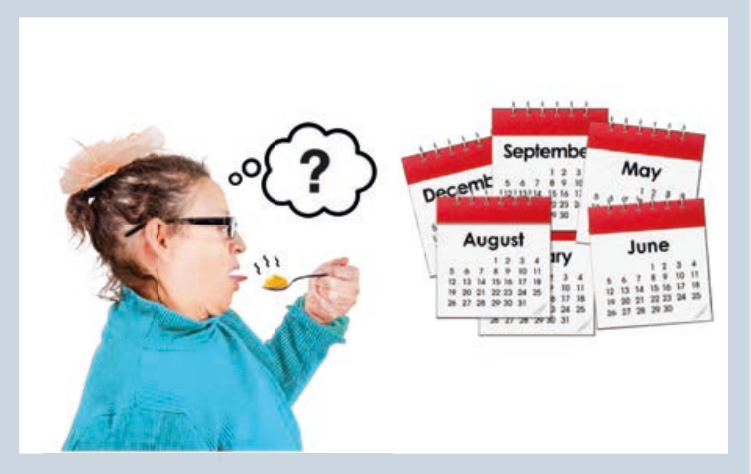

It may take a long time for sense of taste and sense of smell to come back again.

People can feel different symptoms on different days.

Please contact your doctor if you start to feel severe symptoms again.

If you think you have long COVID speak to your doctor on the telephone and see if they can help you.

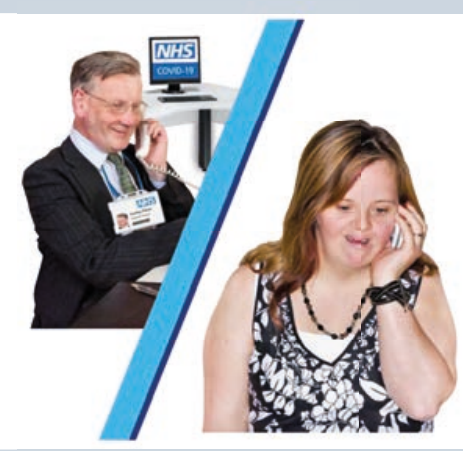




\section{Neurological dysfunction}
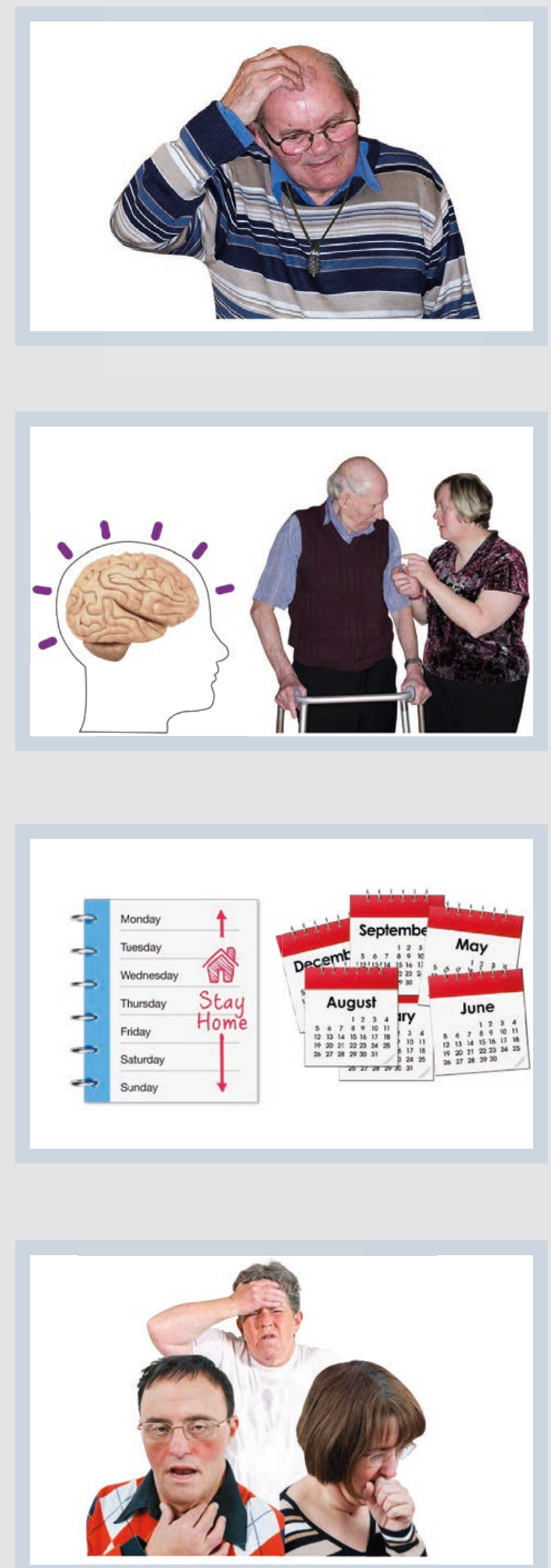

Some people may forget things, get dizzy or confused.

This does not happen to lots of people, but can to older people who have had neurological disease.

These symptoms can last for short or long times.

COVID-19 affects everyone differently. You may have some of the symptoms and not others.

You may have some we have not written about. 


\section{What will happen if I go to hospital?}
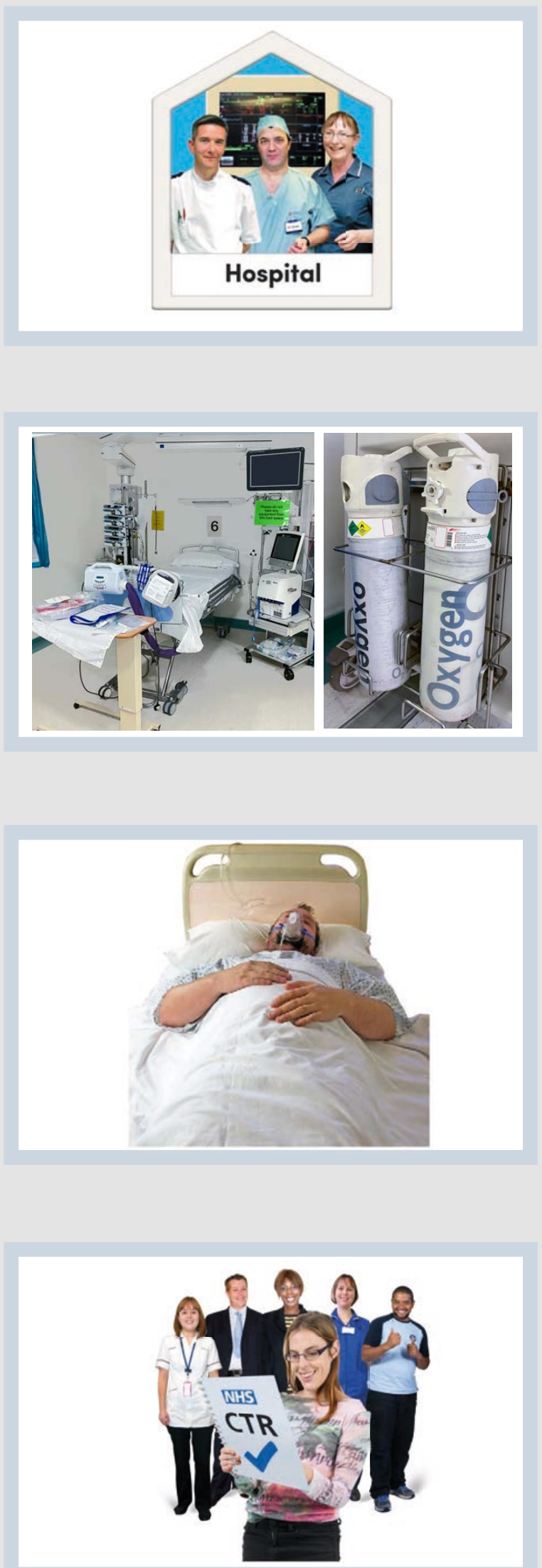

Most people with COVID-19 will not have to go to hospital.

If you do go to hospital, they will check your breathing and may need to give you oxygen to help you breathe.

They may put a mask on your face attached to a ventilator, this is to help you breathe.

The people at the hospital want to help you get better. 

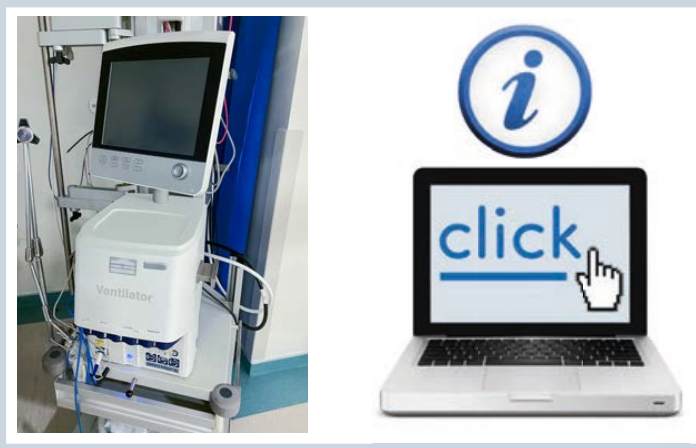

There is more information about ventilation on our website:

\section{What is ventilation -}

www.europeanlung.org/en/ covid-19/covid-19-informationand-resources/covid-19-symptoms

What is ventilation like for the patient -

www.europeanlung.org/en/ covid-19/share-your-experiences/ patient-stories/laura-rentoul

People working in the hospital have to wear special clothes and masks to keep you and them safe.

They will be wearing a mask and plastic shield over their face or goggles on their eyes.
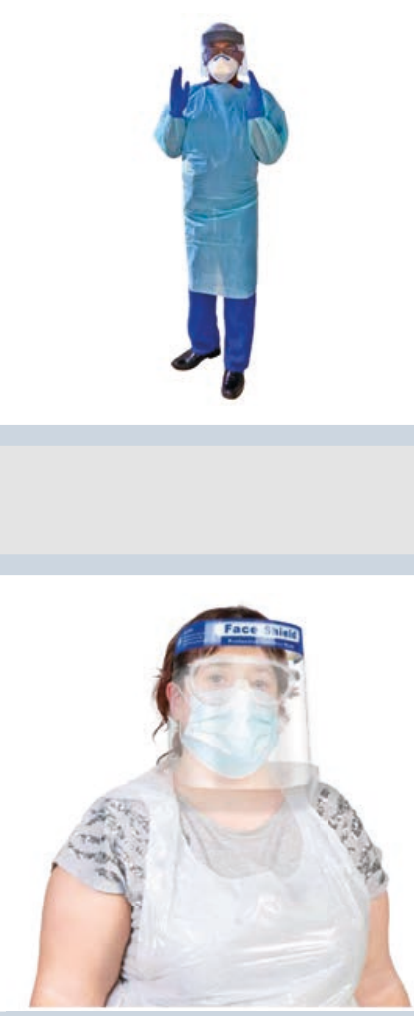
They may have a plastic apron on and unusual clothing.

It may look scary, but they are people trying to help you and keep everyone safe.

\section{Should I get vaccinated?}

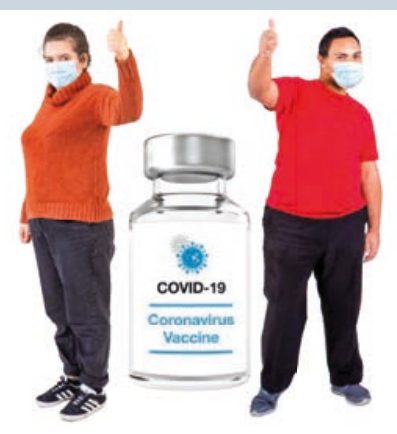

It is very important to get vaccinated, this means having the injection to protect you from catching COVID-19. 

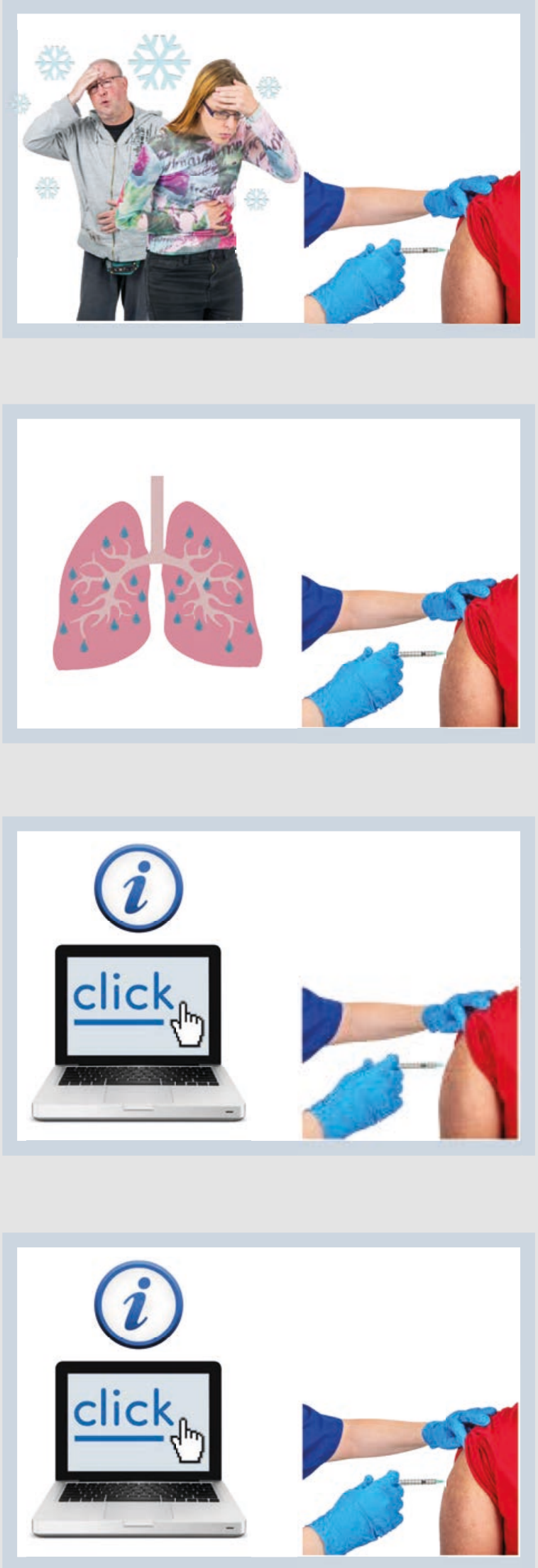

You should also have your flu vaccination as you do each year.

Ask your doctor about getting vaccinated against pneumococcus, they will explain what that is.

We have some information about vaccines on our website:

\section{Vaccine overview:}

www.europeanlung.org/assets/files/ factsheets/vaccination.pdf

\section{COVID-19 vaccine questions and}

\section{answers:}

www.europeanlung.org/en/ covid-19/covid-19-information-andresources/covid-19-vaccinations-\% E2\%80\%93-questions-andanswers-with-ers-president-anitasimonds 

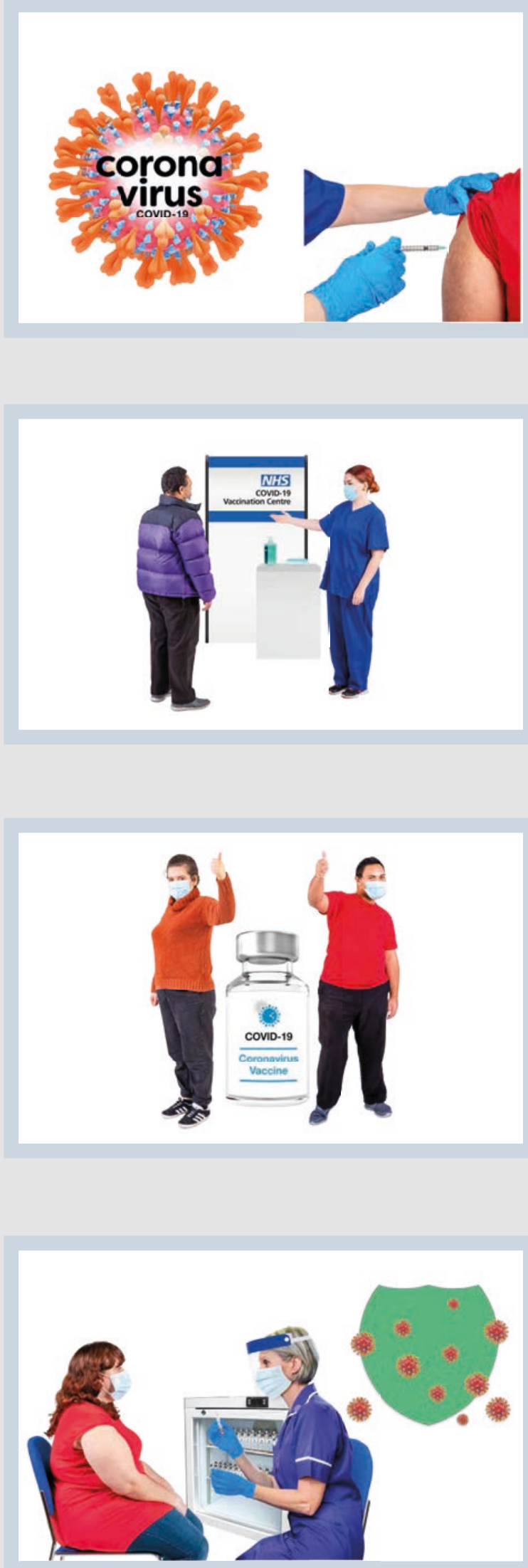

There are vaccines to help protect against COVID-19 and they will be given to the people who need it the most first.

How it is given out will be different in each country.

It is very important to have the vaccination to protect ourselves and people around us from COVID-19.

By having the vaccine you protect people who cannot have it. For example people who are very ill, very old, very young or who may be weak to infection. 


\section{If someone in my house has COVID-19, how do I stop it spreading?}
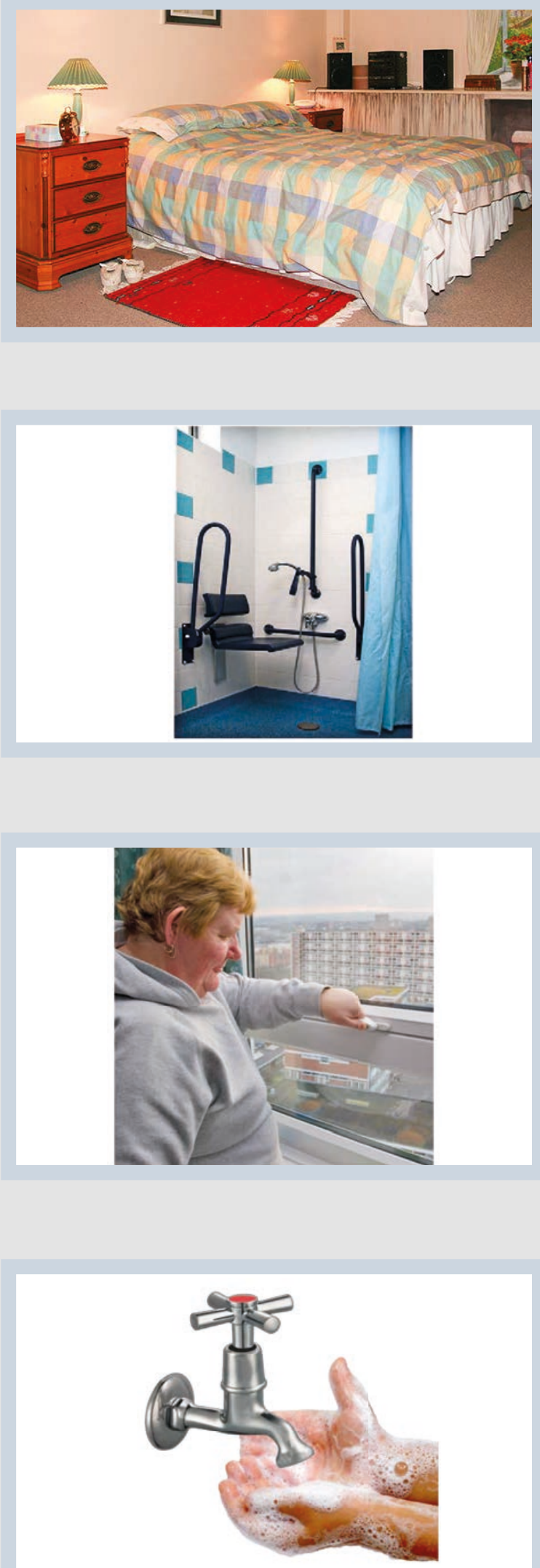

If you or someone in your house has COVID-19 try to:

- Stay in a room on their own

- Use a different bathroom in the house if you can

- Try to have the windows open in the daytime if you can to let fresh air in

- Wash hands often with soap 

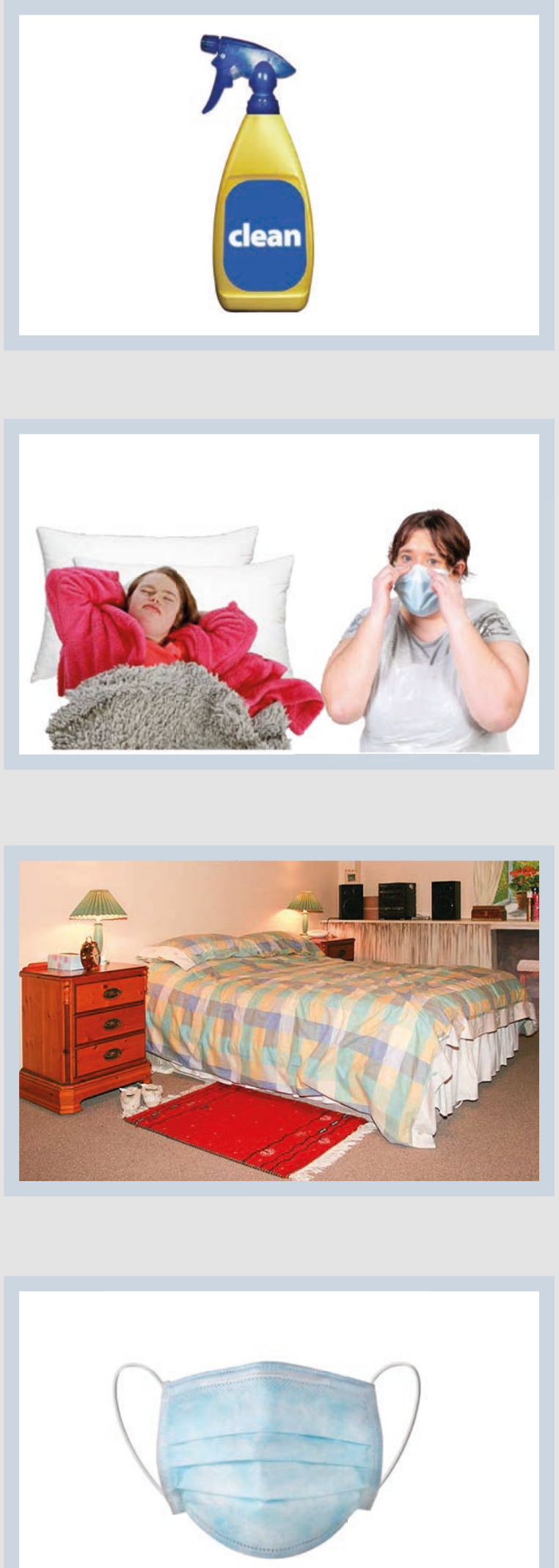

- Clean areas and surfaces that the ill person has touched with soap and water a cleaner called an antiviral detergent

- Wear a face covering if you have to be in a room with them

- Try not to have contact with that person until they are better

- Change your face covering often 


\section{How do I look after how I feel in my mind?}

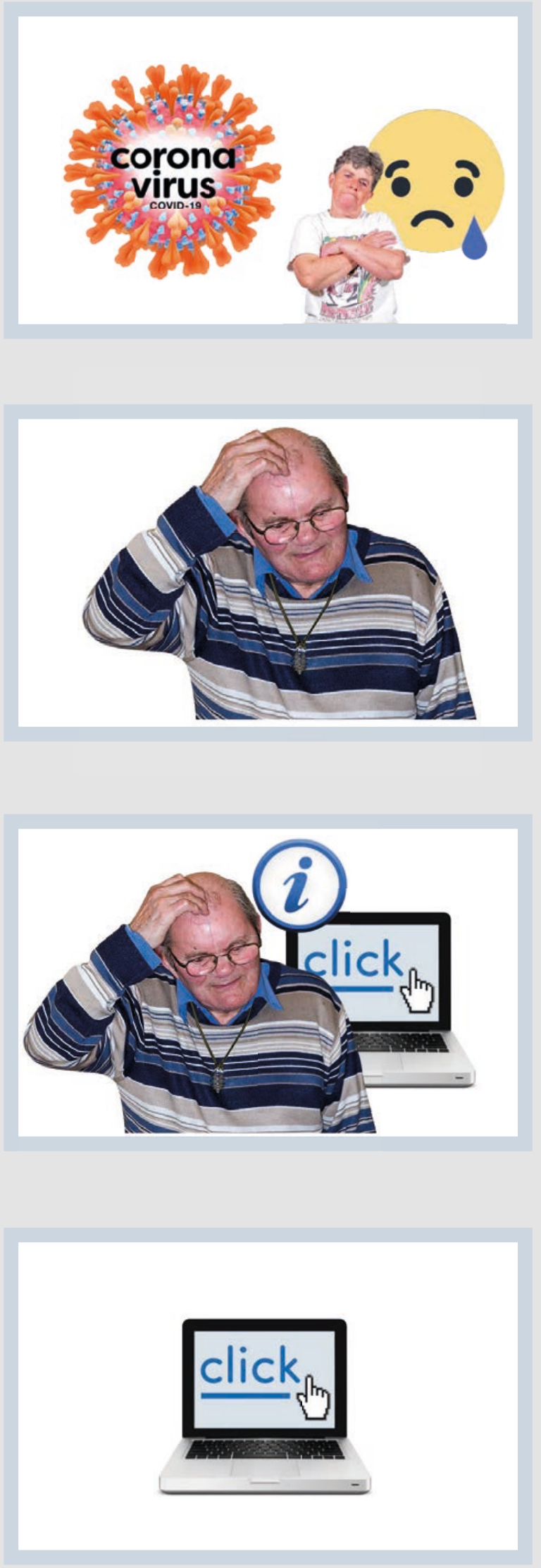

It is hard for people all over the world to have to cope with the COVID-19 virus and how it makes people feel.

It can affect your body and your mind. It is important to look after your mind when you are not feeling well.

We have some information on our website for young people with lung problems about how to look after the mind.

www.europeanlung.org/assets/ files/factsheets/Mental\% 20wellbeing/Mental-wellbeingFactsheet\%20 -\%20D07.pdf 


\section{What are the tests for COVID-19?}
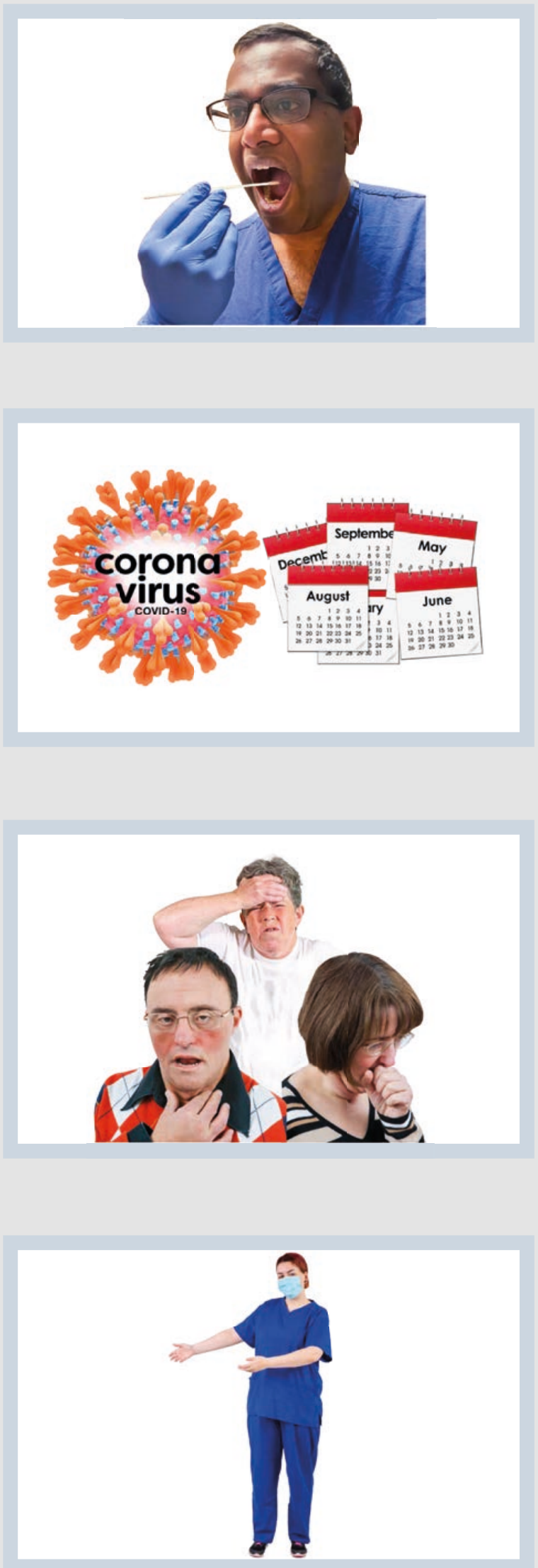

There are 2 main kinds of tests for COVID-19:

1 called a viral (swab) test that tells you if you have the infection now.

1 is called an antibody test, which means they can tell if you have already had COVID-19.

\section{Who should have the viral (swab) test?}

- People who have symptoms of COVID-19

- People who have been asked to have a test by medical or care providers 

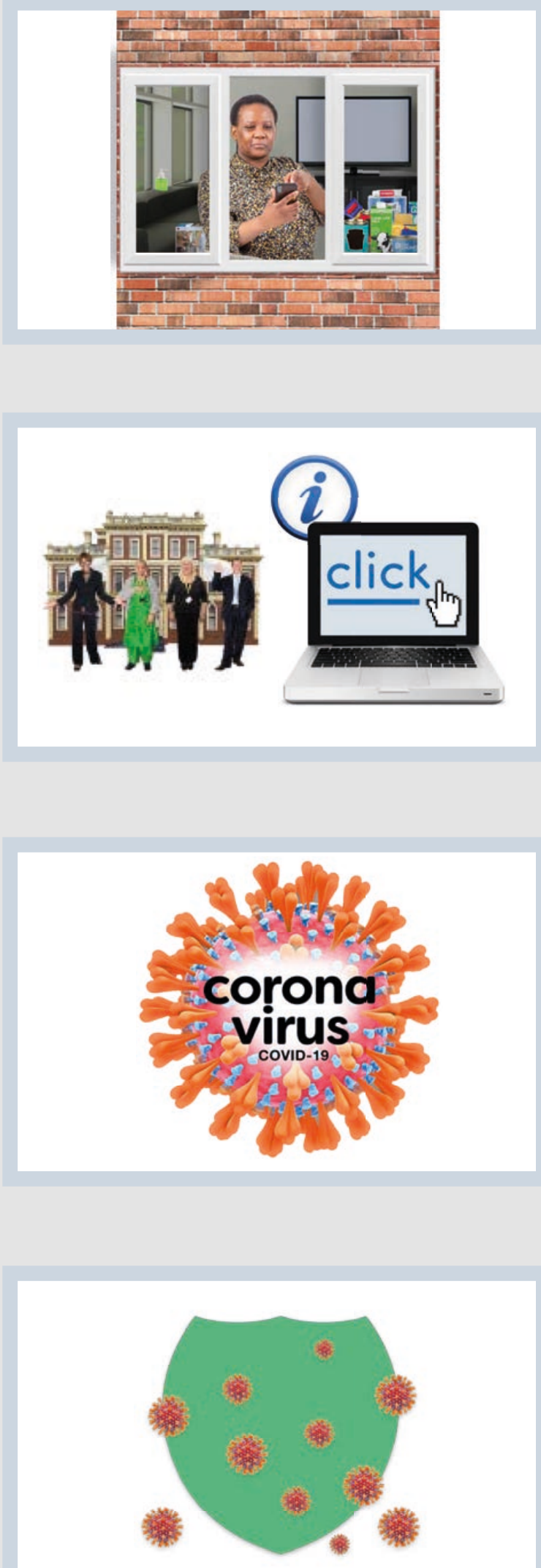
People can catch COVID-19 again, but not many people.

When you touch something with COVID-19 on it, then touch something else, it can spread it.

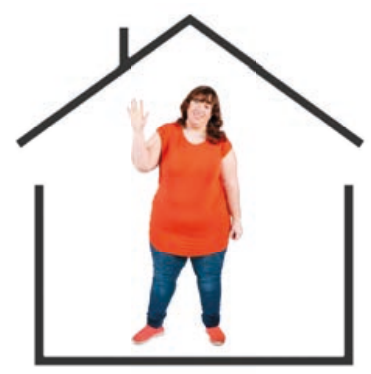

If your test result for COVID-19 is negative, it means you probably did not have it when you were tested.

Who should have an antibody test?

- A doctor may want to know if you have had COVID-19 to understand your symptoms 


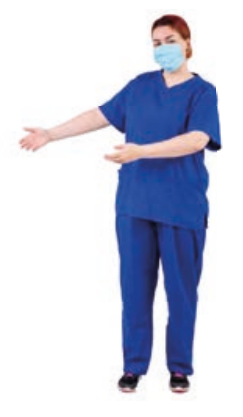

- Some people are helping research about COVID-19, finding out how long people are safe from COVID-19 after having it.

\section{How do I get back to daily living?}
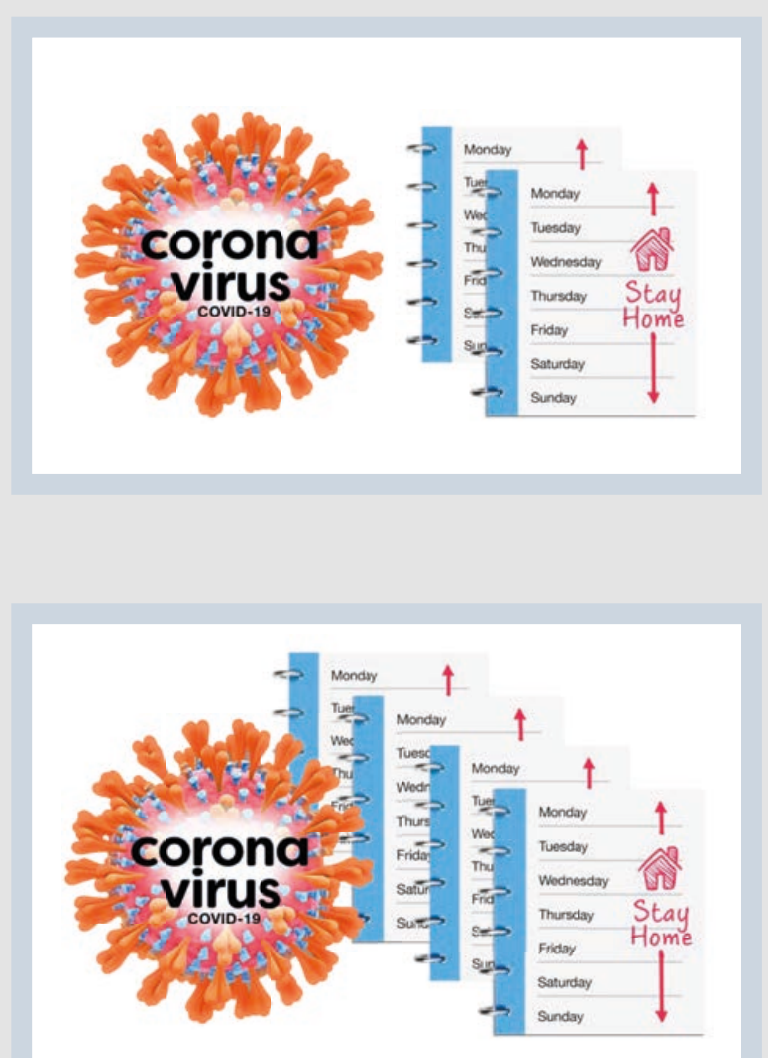

Most people are able to do their normal daily things in about 2 weeks after having COVID-19.

Some people with moderate or severe symptoms of COVID-19 might take longer. 
Even if you just want to get on with your normal life, be careful to get better first.

If you have had moderate or severe COVID-19, you may be able to have physiotherapy or occupational therapy advice to help you do your normal activities.

Physical exercise is important to keep the muscles, heart and lungs strong, gently try to do more when isolation is over.

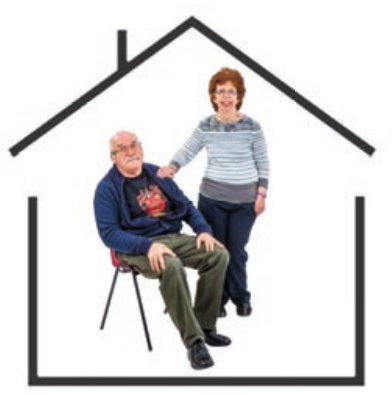

People who have had severe COVID-19 might be given extra help to get stronger. 

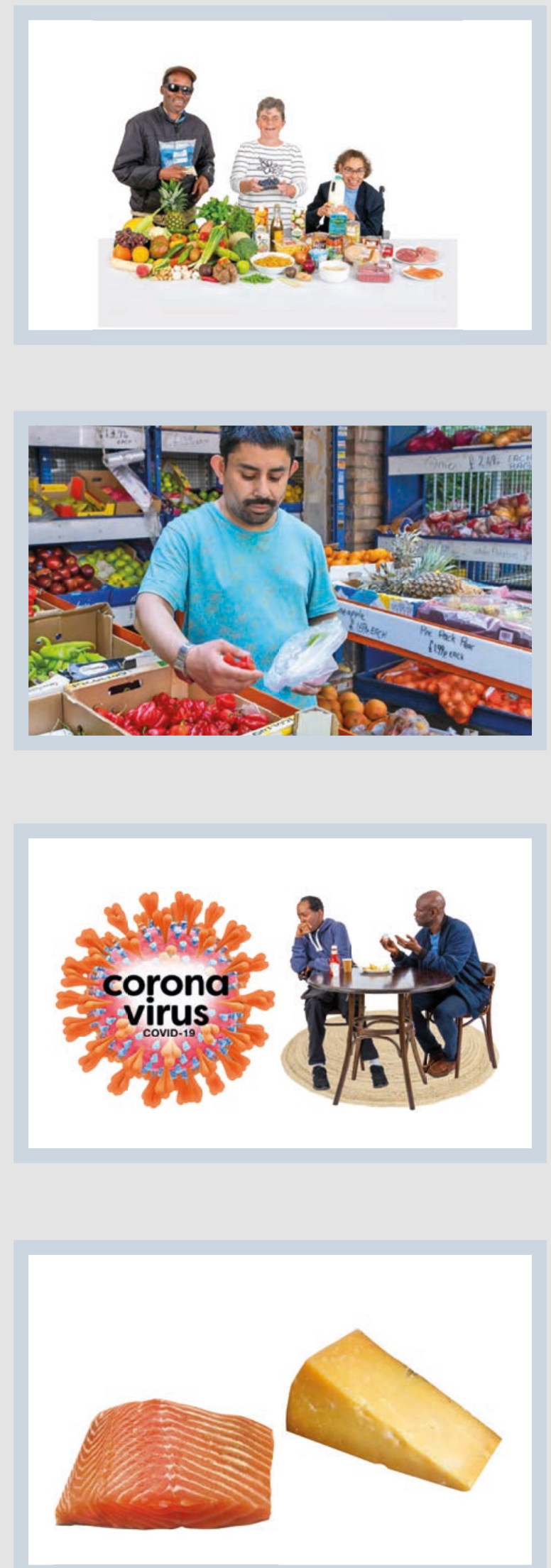

Eating healthily is very important to be well and to help fight off COVID-19.

Try to eat 5-7 or more portions of different colour fruit and vegetables each day.

If you have had COVID-19 you may not have been hungry and might be thin.

Eating foods with lots of protein in are good for you when recovering from COVID-19. Foods like meat, fish, pulses, milk, cheese and vegetarian protein foods. They can help you get strong again. 

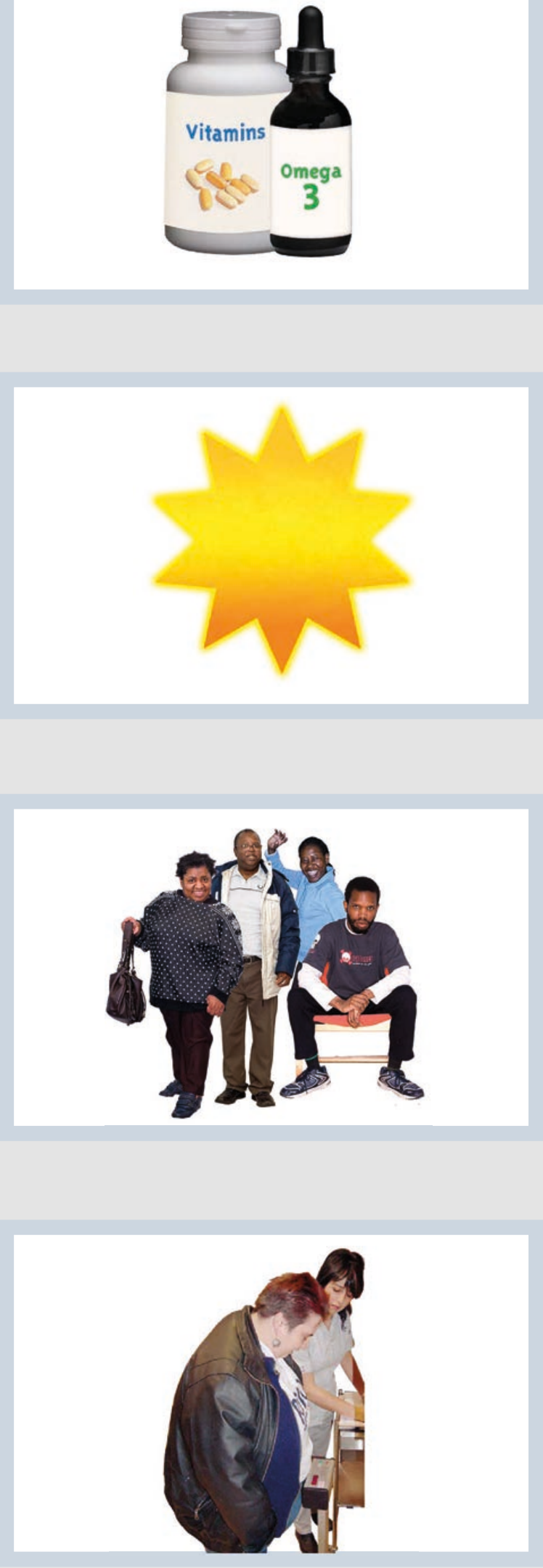

People who do not have enough vitamin $D$ in their bodies can be more likely to get severe COVID-19.

We can get vitamin D from the sun. In the winter and in countries without much sun it can be more of a problem.

Some people from black and minority ethnic groups may be affected more because of their skin colour and the need for vitamin D.

People with bigger bodies may have low vitamin $D$. 

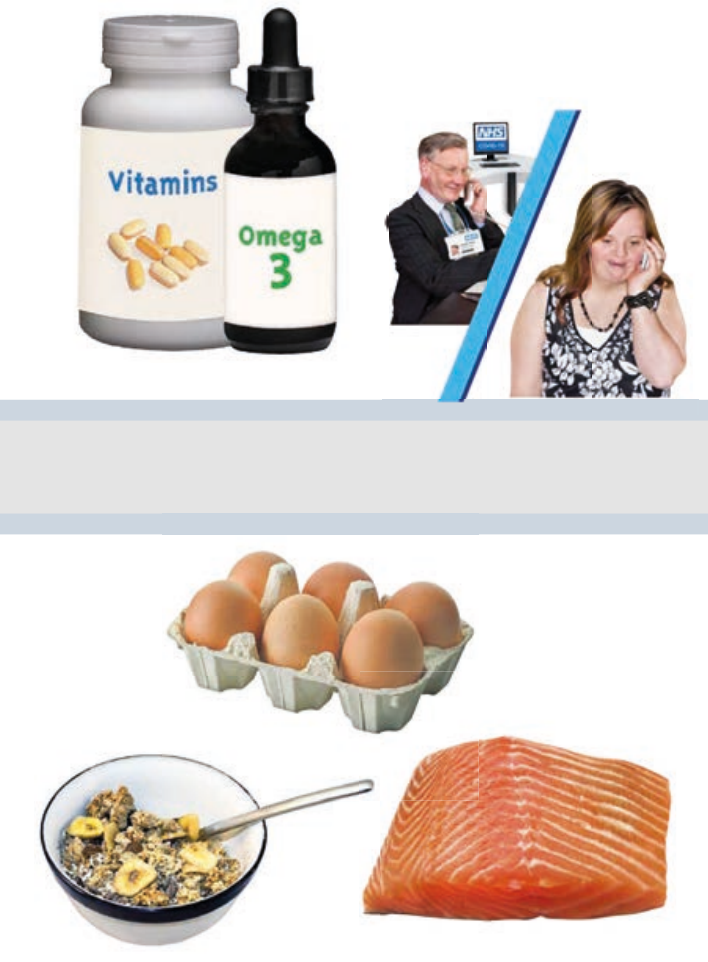

\section{Why is it important I go to my hospital appointments?}

Vitamin D can be eaten in foods like egg yolks, oily fish, fortified foods like cereal, some plant milks and red meat and liver.

If you think you may have low vitamin $D$, speak with your doctor on the telephone.

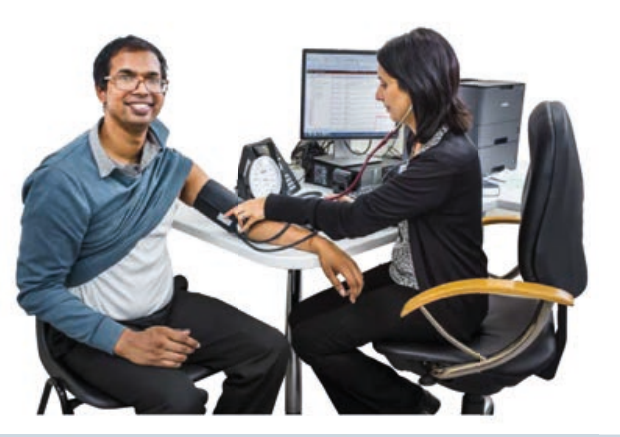

It is important that you look after your health. 

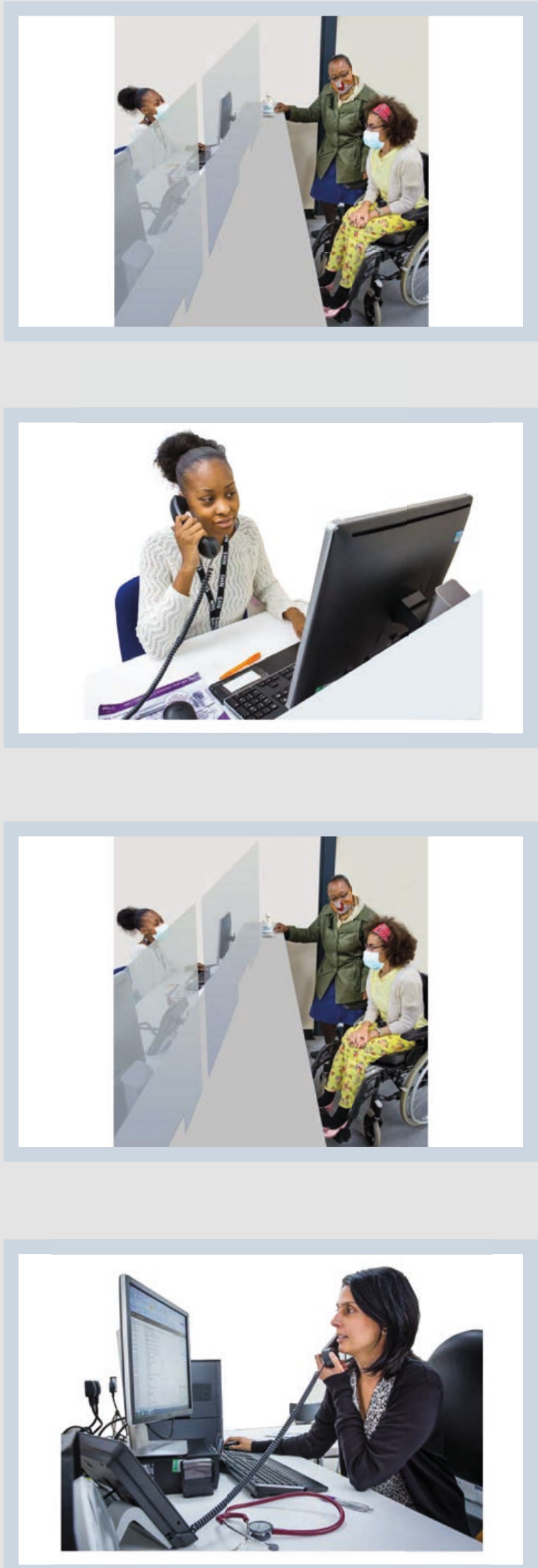

Your regular appointments are important, they may be done a little different to before. Each hospital will have their own way of having appointments.

Some appointments will be on the telephone or on video from your home.

If you do have to go into hospital for an appointment follow the rules about What can I do to help stop me catching or spreading COVID-19?

The hospital may call you before you come in to ask you about any COVID-19 symptoms. 

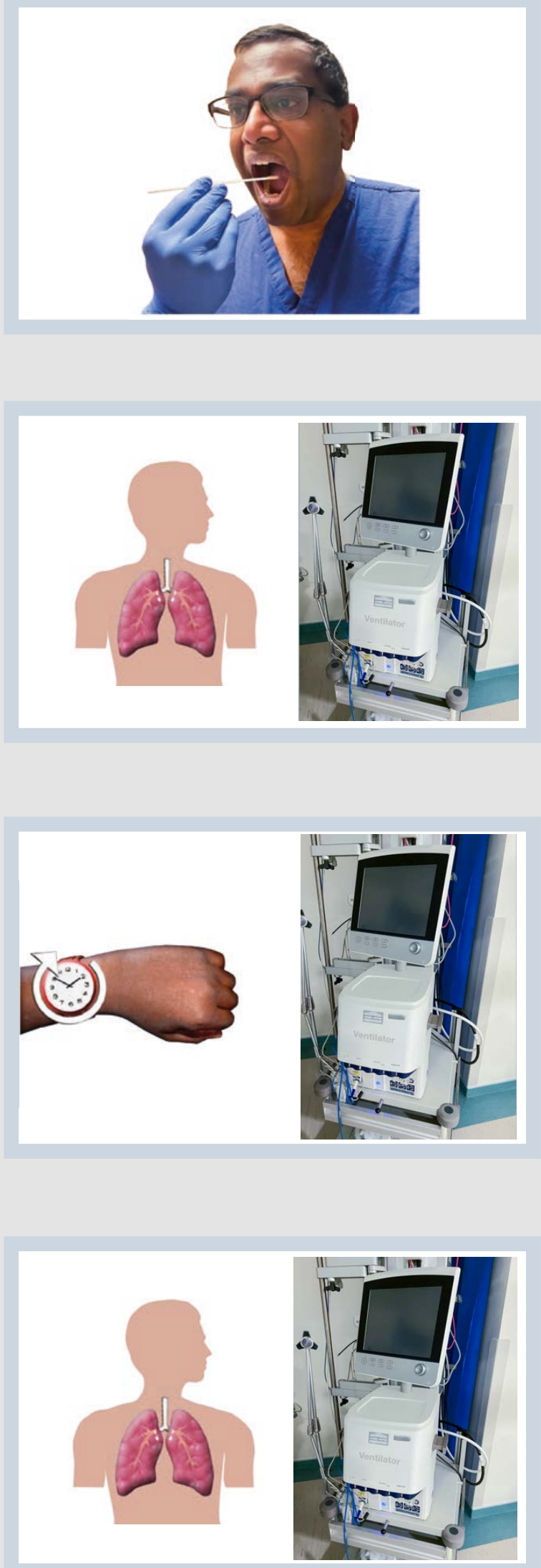

You may be asked to have a viral (swab) test to see if you have COVID-19 and may be asked to stay at home.

Lung function tests, to see how the lungs are working, are still important. Tests like spirometry help understand how to treat you.

We are trying to keep the test the same, but we may need to change some small parts of it. For example, you may have to have the mouthpiece in for longer.

The lung function tests will be safe for you to use. 
The people doing the tests will be wearing a face mask, a visor and clothes to keep everyone safe.

\section{How can I take part in research studies about COVID-19?}
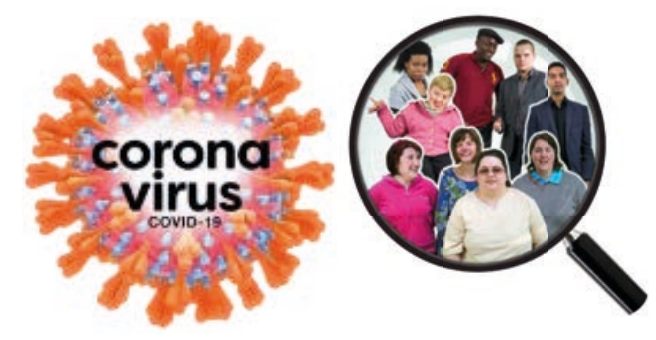

click

是
If you have had COVID-19 and have a lung condition, you may want to help with research. This is to find out more about the virus and how it effects people with lung conditions.

If you are interested in being involved, please email info@europeanlung.org and they can give you more information. 


\section{Useful information}
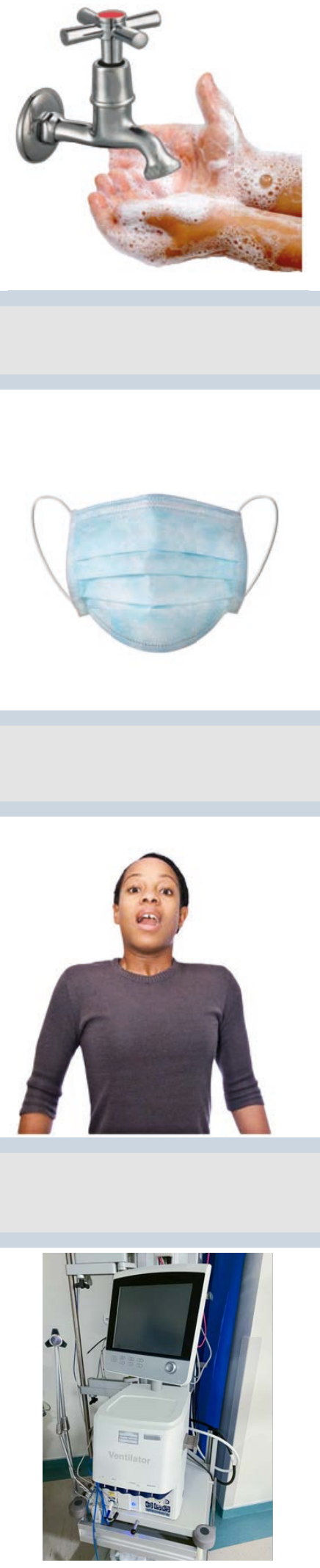

\section{Handwashing -}

www.europeanlung.org/en/ covid-19/what-is-covid-19/ prevention

\section{Face coverings -}

www.europeanlung.org/en/ covid-19/covid-19-information-andresources/wearing-a-mask-or-facecovering-if-you-have-a-lungcondition

\section{Dealing with breathlessness -} www.europeanlung.org/en/ covid-19/covid-19-information-andresources/managingbreathlessness-at-home-during-thecovid-19-pandemic

\section{What is ventilation -}

www.europeanlung.org/en/ covid-19/covid-19-information-andresources/covid-19-symptoms 

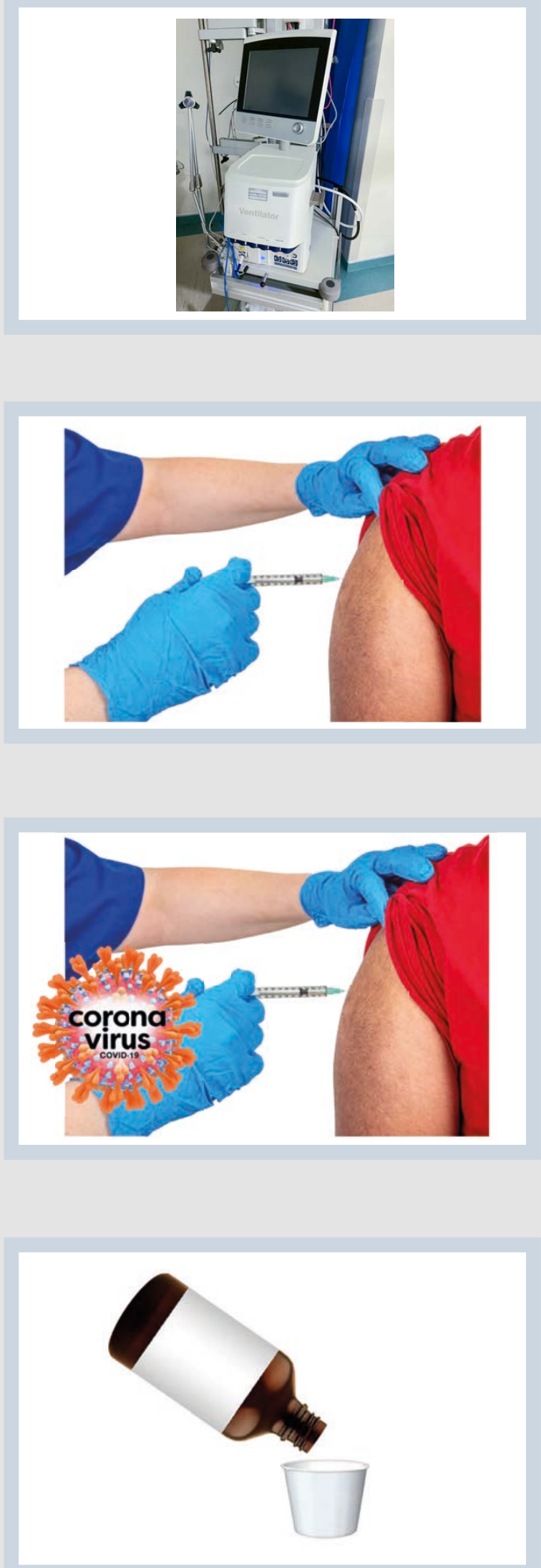

What is ventilation like for the patient -

www.europeanlung.org/en/ covid-19/share-your-experiences/ patient-stories/laura-rentoul

Vaccine overview:

www.europeanlung.org/assets/files/ factsheets/vaccination.pdf

\section{COVID-19 vaccine Q\&A -}

www.europeanlung.org/en/ covid-19/covid-19-informationand-resources/covid-19vaccinations-\%E2\%80\%93questions-and-answers-with-erspresident-anita-simonds

\section{The European Medicines Agency}

- www.ema.europa.eu/en/humanregulatory/overview/public-healththreats/coronavirus-diseasecovid-19/treatments-vaccines/ covid-19-vaccines-key-facts 


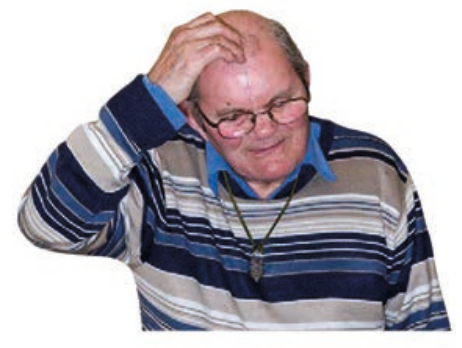

United

Response

support that changes with you

\section{Mental wellbeing -}

www.europeanlung.org/assets/ files/factsheets/Mental\% 20wellbeing/Mental-wellbeingFactsheet\%20 -\%20D07.pdf

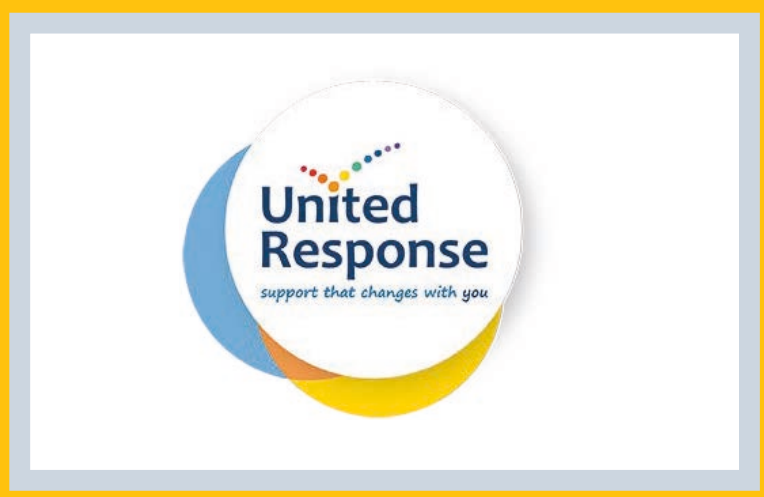

Symimbols
This leaflet was made into Easy Read by UR Consultants, part of the charity United Response: www.unitedresponse.org.uk

With thanks to Photosymbols. 
The European Lung Foundation (ELF) was founded by the European Respiratory Society (ERS) in 2000 with the aim of bringing together patients, the public and respiratory professionals to positively influence lung health.

This information was compiled with the help of Prof. James Chalmers, Prof. Anita Simonds, Dr Sabrina Bajwah, the ELF professional advisory committee and members of the ELF COVID-19 patient advisory group.

This factsheet was produced in January 2021.
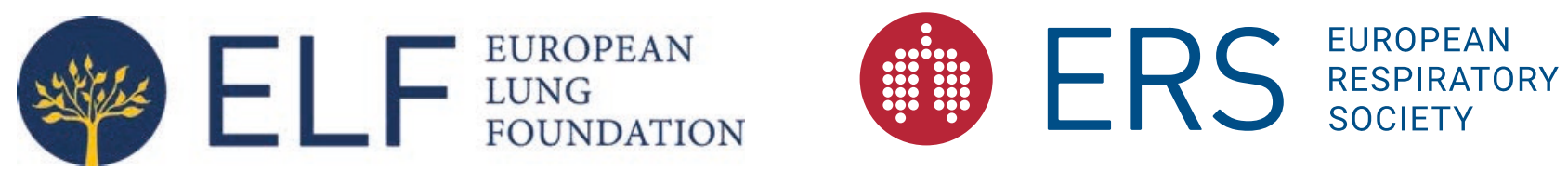

This factsheet was funded by HM Government in partnership with the National Lottery Fund and this work has received support from the EU/EFPIA Innovative Medicines Initiative 2 Joint Undertaking - DRAGON grant $n^{0}$ 101005122. Further information at: https://

www.imi.europa.eu/

The communication reflects the author's view and neither IMI nor the European Union, EFPIA, or any Associated Partners are responsible for any use that may be made of the information contained therein.

\section{\begin{tabular}{l|l}
$\mid \begin{array}{l}\text { In partnership with } \\
\text { HM Government }\end{array}$ & $\begin{array}{l}\text { THENATIONALLOTTERY } \\
\text { COMMUNITY FUND }\end{array}$
\end{tabular}}

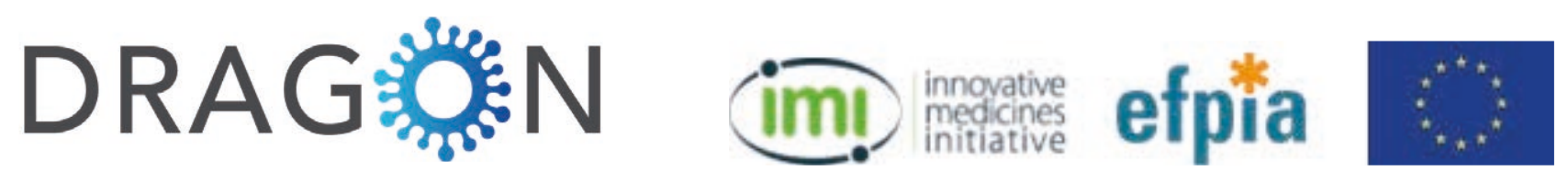

